\title{
Public Finance, Governance, and Growth in Transition Economies: Empirical Evidence from 1992-2004
}

\author{
Taras Pushak, Erwin R. Tiongson, and Aristomene Varoudakis ${ }^{1}$ \\ The World Bank \\ 1818 H Street, NW \\ Washington, DC 20433
}

\begin{abstract}
This paper revisits the early empirical literature on economic growth in transition economies, with particular focus on fiscal policy variables: fiscal balance and the size of government. The baseline model utilizes a parsimonious specification, drawn from Fischer and Sahay (2000), of economic growth as a function of initial conditions, stabilization, market liberalization, and structural reform. The paper expands the data used in previous analyses by up to 10 years and finds unambiguous evidence that fiscal balance matters for growth, while confirming other previous findings on the correlates of economic growth in transition economies. In addition, the paper extends the baseline model and explores potential sources of nonlinearities in the relationship between growth and public finance. A key finding is that determinants of growth may vary in relative importance, depending on the underlying institutional quality. The evidence indicates that there could be higher growth payoffs from macroeconomic stability and public expenditure in countries characterized by relatively better public sector governance as measured by relevant indicators. In addition, the size of government matters for growth in a nonlinear manner: Beyond indicative thresholds of expenditure levels, public spending has a negative impact, while at levels below the threshold, there is no measurable impact on economic growth.
\end{abstract}

JEL Classification Number: P24, P27, O57

Keywords: economic growth, public finance, stabilization, liberalization, initial conditions

World Bank Policy Research Working Paper 4255, June 2007

The Policy Research Working Paper Series disseminates the findings of work in progress to encourage the exchange of ideas about development issues. An objective of the series is to get the findings out quickly, even if the presentations are less than fully polished. The papers carry the names of the authors and should be cited accordingly. The findings, interpretations, and conclusions expressed in this paper are entirely those of the authors. They do not necessarily represent the view of the World Bank, its Executive Directors, or the countries they represent. Policy Research Working Papers are available online at http:/lecon.worldbank.org.

\footnotetext{
${ }^{1}$ Authors' names are in alphabetical order. This paper was prepared as a background for the World Bank's Europe and Central Asia (ECA) Regional Study on Public Finance and Economic Growth. The authors are grateful for comments received from participants at the ECSPE Lunch Seminar series (December 19, 2006) and the Regional Public Finance and Growth Study, Roundtable Discussion (October 26, 2006). Valuable comments and suggestions were received from Cheryl Gray, Pradeep Mitra, and Guillermo Perry. Address all correspondence to: Erwin R. Tiongson, Europe and Central Asia Region, MSN H4-401, World Bank, 1818 H Street, NW, Washington, DC, 20433; telephone 202-458-2773; email: etiongson@worldbank.org.
} 


\section{Introduction}

Governments engage in a variety of functions, through expenditure policies and taxation, mainly to address market failure (i.e., correct externalities and ensure adequate provision of public goods and services), or to fulfill some redistributive goal. These socalled "classical functions" of government have a sound foundation and should be conducive to sustained economic growth and poverty reduction. However, in practice, it has been difficult to determine whether the "optimal" size of government has been reached. It could be argued that while the provision of public goods and services may promote growth, the inefficient provision of these goods, through revenue-raising mechanisms that distort the allocation of resources, may impede growth (see, e.g. Grossman, 1990). More generally, the impact of public finance policies on growth is ambiguous and warrants systematic empirical examination.

What are the conceptual linkages between fiscal policy and growth? For one, the success of fiscal adjustment is thought to be a critical precondition for economic growth. Unsustainable fiscal consolidations are potentially harmful and may weaken investor confidence as they fail to set the government's position on sounder financial footing. Sustained fiscal adjustments are also key ingredients in the creation of long-term fiscal space for growth-enhancing public expenditures.

In addition to sustained fiscal consolidation efforts, the size of government expenditures may also have important consequences for economic growth. In particular, large government expenditure programs are often supported by intrusive regulations that curb private sector activities and investment. They may also require higher levels of taxation that distort the incentives to work, save, and invest. Moreover, as government spending programs grow larger, they may become counterproductive if they are poorly designed. They also promote budget rigidity, thus making it more difficult to maintain control over fiscal balances. In some cases, these larger government programs create new opportunities for rent seeking. The linkages between large government expenditure programs and economic growth may thus be mediated by the quality of public sector governance, an issue that we explore more fully in this paper.

In countries across Europe and Central Asia (ECA) ${ }^{2}$, substantial fiscal consolidations have been a key characteristic of the transition to a market economy, with a mixed record of success. There has also been a remarkable evolution in the size of government and government expenditure programs, with large variations across countries. Over the transition period, there have also been significant variations in the magnitude and direction of economic growth. The experiences of the countries in the region thus present an opportunity to revisit the empirical links between public finance and economic growth.

\footnotetext{
${ }^{2}$ These economies include Albania, Armenia, Azerbaijan, Belarus, Bosnia \& Herzegovina, Bulgaria, Croatia, Czech Republic, Estonia, FYR Macedonia, Georgia, Hungary, Kazakhstan, UNMIK/Kosovo, Kyrgyz Republic, Latvia, Lithuania, Moldova, Montenegro, Poland, Romania, Russian Federation, Serbia, Slovak Republic, Slovenia, Tajikistan, Turkey, Turkmenistan, Ukraine, and Uzbekistan.
} 
Based on evidence from countries in ECA over the 1992 to 2004 period and using a newly constructed fiscal data set by the World Bank, the empirical analysis in this paper explores three possible linkages between public finance policies and growth: (i) how fiscal deficits affect growth; (ii) the impact of the size of government on growth; (iii) linkages with the quality of governance. With respect to the first two components, the paper utilizes more recent data, a longer time series, and a broader, more representative sample of countries, representing an improvement over the existing literature. As for the third component, the growth-expenditure-governance nexus has not been systematically investigated in previous studies, although there is growing indirect evidence that the quality of public institutions mediate the impact of the key drivers of growth (see, for example, Burnside and Dollar 2000 and 2004).

The main results of the empirical analysis in this paper confirm that a sound fiscal position is associated with higher growth in ECA. Lower fiscal imbalances, which are associated with greater macroeconomic stability, less business uncertainty, and a stronger investment climate, are in turn, conducive to higher growth. However, the size of the public sector also affects economic growth in a nonlinear manner. At some indicative level of government expenditures in percent of GDP or higher, public spending has a measurable negative impact on economic growth, while at levels below that threshold, government size has no robust effect on growth. The quality of governance mitigates the negative impact of public sector size on growth: Public sector size impinges on growth in countries characterized by relatively weaker government effectiveness and public sector institutions, but there is no significant evidence of a negative impact when governments are relatively more effective.

The rest of the paper is organized as follows: Section 2 provides a review of literature on fiscal policy and growth. Section 3 presents the baseline model used in the analysis and its motivation. It also discusses the extensions to the baseline model. Section 4 discusses the data sources and some specification issues. Section 5 reports the main findings from the analysis and discusses their implications. Section 6 concludes.

\section{Review of Related Literature on Fiscal Policy and Growth}

The growth literature in transition economies is still relatively in its infancy, particularly in the assessment of the links between growth and public finance, owing in large part to data constraints. In fact, it has only been about ten years since the emergence of the first empirical studies of economic growth in transition economies (e.g., Sachs 1996; de Melo et al 1996; Selowsky and Martin 1997). While the broader empirical literature on economic growth has been notoriously unwieldy-a recent metastudy identifies some 67 variables thought to be significant correlates of growth, based on existing studies (Sala-i-Martin, Doppelhofer, and Miller, 2004) — there has been, in contrast, a remarkable consensus on the determinants of economic growth in transition economies. These studies - numbering over 20 published papers as of 2002-are reviewed by Havrylyshyn (2001) and Campos and Coricell (2002). The significant 
variables may be classified under three broad groupings: (i) measures of macroeconomic stabilization; (ii) market liberalization and structural reform; and (iii) initial conditions. In addition to the remarkable consensus around the key drivers of growth, there is also a striking consensus on what are not determinants of growth, in contrast to the broader literature on economic growth. For example, "traditional factor inputs" have not been found to explain growth in transition economies (Havrylyshyn 2001). Furthermore, two variables have not been found to have a statistically significant link with economic growth, unlike the rest of the literature: exports and foreign direct investment (FDI).

Despite this consensus, a number of issues are left unresolved in the empirical literature on growth in transition economies, particularly with respect to the role of fiscal policy. These issues are outlined below.

Does fiscal stability matter for growth? The impact of macroeconomic stabilization on economic growth is generally uncontroversial. Stabilization is typically measured using the natural log of inflation and its negative impact on growth and its statistical significance have been generally unambiguous. However, the results with respect to fiscal balance (in percent of GDP) — a complementary measure of stabilization-have been mixed (e.g., Fischer and Sahay 2000; Havrylyshyn 2001; Purfield 2003), at least in the literature on transition economies. In the literature on advanced and developing economies, there have been stronger evidence in support of the growth-enhancing effects of fiscal stability. Gupta and others (2002), for example, find that strong budgetary positions as well as fiscal consolidation are associated with higher economic growth in both the short-term and the long-term.

The role of public investments or "productive" expenditures. The broader literature on economic growth, drawing from developing country as well as developed country experiences, yields a mixed record for the impact of public investment on economic growth. In an effort to estimate how the structure of taxation and the composition of public expenditures affect growth rates of a country, Kneller (1999) uses data for 22 OECD countries (1970-1995) to expenditures with a substantial (physical or human) capital component are classified as "productive” while social security and other expenditures were considered "unproductive" Not surprisingly, the paper concludes that productive government expenditure promotes economic growth, while non-productive expenditure does not. ${ }^{3}$

While not explicitly classifying expenditures productive or unproductive, Gupta and others (2002) use a panel of 39 low-income countries between 1990 and 2000 and find that the composition of public outlays is important: Where spending is disproportionately allocated to wages, countries have tended to experience lower growth, while countries that allocate higher shares of spending to capital and non-wage goods and services have experienced more rapid economic expansion. In particular, the results suggest that a one percent increase in the allocation of public spending to capital outlays can raise the growth rate by 0.1 percentage point in the long term and by almost 0.5 of

\footnotetext{
${ }^{3}$ Interestingly, the analysis shows, that magnitude of the estimated impacts of (productive) expenditures and (distortionary) taxation are sensitive to the process of (5-year) averaging of the data.
} 
one percentage point of GDP in the short term. Bose (2003) also finds that the share of government capital expenditure in GDP is positively and significantly correlated with economic growth, though current expenditure is insignificant. The study is based on a panel sample of 30 developing countries over the period between 1970 and 1990. At the sector level, government investment and total expenditures in education appeared to be the only outlays significantly associated with growth, once the budget constraint and omitted variables were taken into consideration. Analysis of both total expenditure in education and investment in education provide support to this conclusion.

However, a recent review (IMF 2004) suggests weak links between public investment growth that may be due to a number of factors, including the narrow scope of public investment as a measure of productivity-enhancing expenditure components (i.e., social spending may boost the stock and quality of human capital); the use of gross rather than net investment (i.e., gross public investment minus depreciation) imperfectly measures the net addition to the public capital stock; and physical indicators (e.g., share of paved roads) may be a better measure of productive investment, as they measure the output of public investment that may have a more direct, causal effect on growth.

Are the key drivers of economic growth time-varying? In his review of the first decade of empirical research on growth in transition economies, Havrylyshyn (2001) suggests that larger samples may permit the further refinements to the general consensus, to show, for example, how some variables may be relatively important initially, but may decline in importance over time. Similarly, using larger samples, it may be possible to show how the impact of public finance may have evolved over time. A broad consensus emerged from the first decade of empirical research on growth in transition economies. Since then, some recent studies have updated the data used in the analysis through 2001 (e.g., Godoy and Stiglitz 2006) and questioned the relative importance of some of the key variables from the early literature (e.g., structural reform). Thus one possibility is the shifting relative importance of the main determinants of growth in transition economies. In particular, transition economies have made significant advances in macroeconomic stabilization and structural reform over time. This leads us to expect that the "firstgeneration" determinants of growth may have weaker impact in recent years. Where there remains an unfinished policy agenda, such as in fiscal consolidation, we would expect variables such as fiscal balances to have significantly more perceptible effects on economic growth.

Does the size of government matter for growth? There appears to be no existing consensus on the appropriate size of government (see Gupta et al 2003 for a review of the literature). Nonetheless, assessing desirable levels of expenditure is critical because excessive levels of spending not aligned with available resources may lead to unsustainable deficits, which in turn may trigger macroeconomic instability (Devarajan et al 2001). In addition, some have speculated that disproportionate levels of expenditure may have adverse effects on economic growth. De la Fuente (1997) provides evidence in support of the view that government expenditures have a negative impact on income levels and growth rates. Based on the sample of selected OECD countries (two periods: 1960-1993 and 1970-1995), evidence suggests that a reduction of total government 
expenditures would increase the annual growth rate of the average EU country.

Moreover, public expenditure tended to crowd out private investment by reducing private disposable income and the incentive to save. The estimates indicate that each \$1 increase in government expenditures reduced private investment by about $\$ 0.32$. De la Fuente also found empirical evidence that increases in the overall size of government-measured by the share of total government expenditures in GDP — are associated with a sizable reduction in the level of productivity through an "externality effect" arising from various types of distortions.

Grossman (1990) provides a succinct summary of the literature on growth and the size of government: on one hand, the provision of public goods and services in principle contributes positively to growth; on the other hand, this also may contribute negatively to growth through the inefficient provision of these goods and revenue-raising mechanisms that distort the allocation of resources. Meanwhile, Fischer and others (1996) suggest that sharp reductions in expenditures at very large scales seen during the early transition may themselves have negatively affected the reform process.

The empirical literature on economic growth in transition economies have generally found, or assumed, that the standard determinants of growth do not apply to transition economies. Thus few papers discuss explicitly the link between government expenditure and growth in transition economies. These papers-such as those that produce long-run growth projections for transition economies (Fischer and others 1998; Coricelli 1997; Wagner and Hlouskova 2005)—assume based on findings from standard empirical models of growth that a significant, negative link exists. For example, rather than test the statistical link between public expenditure and growth in transition economies, Fischer and others (1998) produced long-term growth forecasts for these economies based on Barro's (1991) growth equation, which models growth as a negative function of government consumption. Wagner and Hlouskova (2005) follow the same "indirect approach," using growth regressions results based on the older EU member states to make projections for the new EU member states, based in part on a negative link between public consumption and growth.

Fidrmuc (2001) has criticized this indirect approach of using existing growth equations and has argued that growth forecasts for transition economies need to account instead for "transition-specific" factors. In addition, Barro's (1991) findings with respect to size of government are not definitive. Levine and Renelt (1992) are unable to find robust significant links between government expenditure and growth, although they find that the relationship is generally negative. Some have suggested that there may be "thresholds" in the links between size of government and growth (Chen and Lee 2005). It has also been argued that the composition of government expenditure matters (Devarajan and others 1996).

What do we know of the statistical link between public expenditure and growth in transition economies, from studies that have actually sought to examine it? First, the evidence on the links between the size of government and growth is inconclusive. Chu and Schwartz (1994) find insignificant links while Campos (2000) finds a positive, 
though generally insignificant, impact of government consumption on growth. Beck and Laeven (2005) find a negative, insignificant link between government consumption and average GDP per capita growth while Brunetti, Kisunko and Weder (1997) find a positive insignificant link. Second, the empirical work has been subject to severe data constraints. Many of the reported regression results are, in fact, based on very small sample sizes. Fidrmuc and Tichit (2004) are unable to incorporate a measure of government consumption in their growth regression because this effectively reduces the number of observations by over a third of their sample size. Beck and Laeven (2005) use 24 observations while Brunetti and others (1997) use a sample of about 18 observations. Third, there is recent evidence of a significant negative link between public spending and growth. Åslund and Jenish (2005) suggest that expenditure reductions have underpinned economic growth in the region from 1999 onwards, particularly among CIS countries. Fourth, some have suggested that the relationship between the size of government and growth may be nonlinear. Barro (1990) presents a theoretical model of endogenous economic growth that yields a nonlinear (inverted $U$ ) relationship between the rate of growth of per capita income and the size of government. Bajo-Rubio (2000) reproduces this same relationship but in a more general (Solow) growth model. There have been few empirical investigations of this nonlinear relationship. Chen and Lee (2005), examine the data on Taiwan and suggest that there may be a threshold level of public expenditure (in their case, the threshold is about 23 percent of GDP for total government consumption) under which government expansion has a positive impact on growth and beyond which there can be adverse effects on growth. ${ }^{4}$ To the best of our knowledge, this dimension of economic growth has not been systematically investigated using data on transition economies.

Does the institutional quality matter? Are there measurable differences in the growth performance and its correlates between countries with relatively lower institutional quality and countries with relatively higher institutional quality? In particular, does government efficiency matter for the impact of expenditure on growth? While, to the best of our knowledge, this has not been investigated in the growth literature, there is plenty of indirect evidence that the quality of public institutions mediate the impact of the key drivers of growth. See, for example, the literature on aid, growth, and good policies (Burnside and Dollar 2000 and 2004).

How can good governance mitigate the negative impact of big governments? Given public sector institutions, governance, and social preferences, the marginal benefit of public expenditure is expected to fall as the size of expenditure programs grows larger. Similarly, the marginal cost of taxation is expected to increase as the tax burden rises, recognizing that high taxes may distort the incentives to invest and participate in the labor force. Although internal political dynamics may complicate outcomes, public expenditures in a given country would be expected to increase until their marginal benefits equal the marginal cost of taxes required for their financing (Figure 1, point A).

\footnotetext{
${ }^{4}$ Other empirical studies of this nonlinearity include Grossman (1988), Dowrick (1996) and a very recent study of East Asian economies (Knowles and Garces-Ozanne 2003).
} 
Better quality of public sector governance may be expected to affect both determinants of government size: First, the marginal benefit of a given level of public expenditures rises. In particular, program design, resource management, and service delivery would improve outcomes, for example, in health care or education. At the same time, the marginal cost of a given level of taxes falls, as better tax administration and tax policy can help raise revenues in less distorting ways. With better-than-average quality of governance (as in many high-income OECD countries), the "optimal” size of government — as measured by the size of public expenditures and taxes - could thus increase compared to a typical country (Figure 1, point A*). In this case, a larger government would not necessarily exert a negative impact on efficiency and growth.

Figure 1. Governance Quality and the Optimal Size of Government

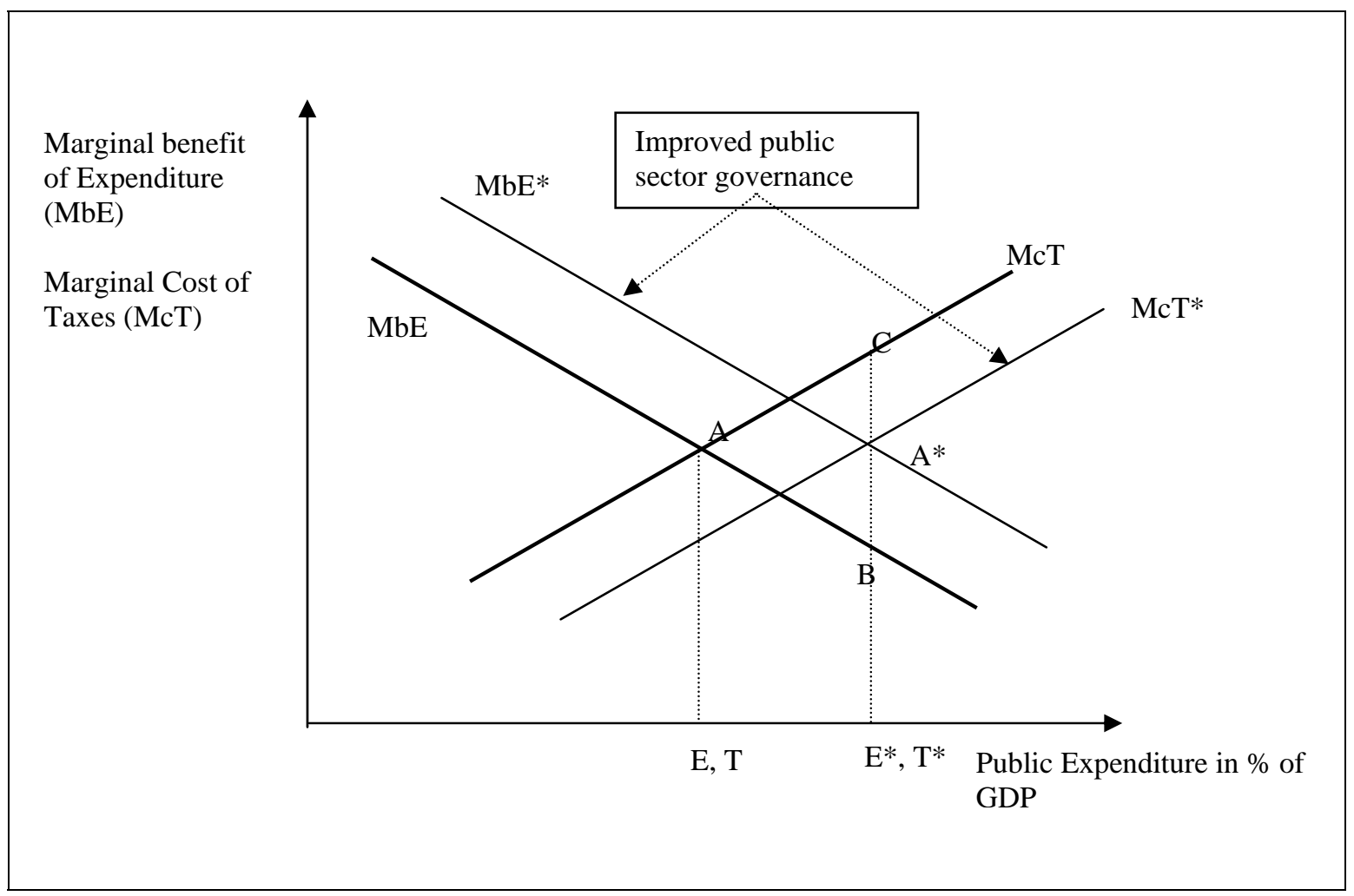

In the case where public expenditures and taxes in the typical country (with average quality of governance) both rise to the levels represented by $\mathrm{E}^{*}$ and $\mathrm{T}^{*}$, a gap is effectively created between a higher marginal cost of taxes (point C) and a lower marginal benefit of expenditures (point B). This misalignment of marginal cost and benefits, as is well-known in the literature, creates an efficiency loss (or "deadweight loss"), represented by the familiar "Harberger triangle" ABC. We expect that the larger the efficiency loss, the bigger the negative impact of a larger government size on growth. On the other hand, efficiency losses will not be significant unless the size of government exceeds the "optimal size." The association of large public expenditures with lower economic growth, beyond a certain threshold of expenditure, when the quality of governance remains weak, is corroborated by the empirical findings in the next section. 
This paper updates the early empirical literature on economic growth in transition economies, with particular focus on fiscal policy variables (fiscal balance as well as the size of government and selected expenditure components). It expands the panel data sample, relative to the existing literature, by some 7 to 10 years of additional data, representing a doubling of existing sample sizes. It utilizes a parsimonious model drawn from Fischer and Sahay (2000) of economic growth as a function of initial conditions, stabilization, liberalization and structural reform, consistent with existing empirical literature.

Allowing for the possibility that the coefficient estimates of the Fischer-Sahay model may vary over time and by quality of governance, as explained in the next section, this note expands the earlier literature by focusing on potential sources of nonlinearities: First, it explores the possibility that the key drivers of economic growth may be shifting in relative importance over time. Second, it allows for the possibility that the determinants of economic growth may vary in significance and importance, depending on the country-specific quality of governance or public sector institutions. The correlates of growth that may depend on the underlying institutional quality include such variables as public investments. Third, it allows for the possibility that there are measurable thresholds in the impact of the size of government on economic growth.

\section{Empirical Framework: Baseline Model and Extensions}

In general, as previously discussed, three broad conclusions on the underlying determinants of economic growth in transition emerge from the first decade of empirical analysis (see, for example, Havrylyshyn 2001; Campos and Coricell 2002; World Bank 2002). These studies draw from both cross-sectional studies and panel data analyses and conclude that the following matter significantly for economic growth: (i) macroeconomic stabilization; (ii) market liberalization and structural reforms; and (iii) initial conditions. The specific measures and indexes of macroeconomic stabilization (fiscal balance, inflation, or some other measure), reform, and initial conditions have tended to vary from one study to another, but the broad findings have tended to be robust.

\section{Baseline model}

This note utilizes a parsimonious regression model drawn from Fischer and Sahay (2000) reflecting the findings of the first decade of empirical research. In particular, our baseline specification is of the following general form:

$$
G r_{i, t}=\beta_{0}+\beta_{1} W D_{i, t}+\beta_{2} I N F_{i, t}+\beta_{3} F I S_{i, t}+\beta_{4} E B S M_{i, t}+\beta_{5} E B L I B_{i, t}
$$

where $G R_{i, t}$ is the real GDP per capita growth rate; $W D_{i, t}$ is a war dummy or an index of armed conflict; $I N F_{i, t}$ is the natural log of inflation; $F I S_{i, t}$ is the fiscal balance in percent of GDP, with positive values denoting fiscal surpluses; and $E B S M_{i, t}$ and $E B L I B_{i, t}$ are the 
European Bank for Reconstruction and Development (EBRD) indexes of small-scale privatization and price liberalization, respectively, with higher values indicating greater progress in structural reform ${ }^{5}$; and $i$ and $t$ are country and year indexes, respectively. The independent variables correspond to measures of initial condition $(W D)$, macroeconomic stabilization (INF and FIS), and liberalization or structural reform (EBSM and EBLIB). Alternative measures of initial conditions are a set of indexes developed by de Melo et al (1996) based on principal components analysis. Based on the existing literature we expect $W D$ and $I N F$ to be negatively, and $F I S, E B S M$ and $E B L I B$ to be positively, related to growth; that is $\beta_{1}<0$ and $\beta_{2}<0$ and $\beta_{3}>0, \beta_{4}>0$ and $\beta_{5}>0$.

An alternative measure of policy reform is the overall index of reform progress (IRP) which is the unweighted sum of the EBRD indexes of reform. This measure follows Sachs (1996), although Sachs used only a simple bivariate model of economic growth for the 1990 to 1995 period. ${ }^{6}$ Fischer and Sahay (2000) use a similar composite measure, drawn from three indexes of reform. Substituting IRP into equation (1) yields the following regression model:

$$
G r_{i, t}=\beta_{0}+\beta_{1} W D_{i, t}+\beta_{2} I N F_{i, t}+\beta_{3} F I S_{i, t}+\beta_{6} I R P_{i, t}
$$

\section{Extensions}

Following the early literature, we use Ordinary Least Squares (OLS) to estimate equation (1). To test the robustness of the baseline results and account for cross-country heterogeneity, we also utilize other econometric methods, such as fixed effects (FE) and random effects (RE) estimators. In addition, we expand the baseline model to explore some additional questions:

Are the key drivers of economic growth time-varying? Rather than treat the relative importance of the drivers of growth in a static sense, we nest the findings from the early literature and the more recent literature in a single framework, by allowing they key coefficients to vary over time. This allows for the possibility that some elements may have been key drivers of growth in the early transition period, but may have diminished in importance over time, or vice-versa. This suggests the following regression models:

$$
\begin{array}{ll}
G r_{i, t}=\alpha_{0}+\alpha_{1} W D_{i, t}+\alpha_{2} I N F_{i, t}+\alpha_{3} F I S_{i, t}+\alpha_{6} I R P_{i, t} & \text { at } t<t^{*} \\
G r_{i, t}=\alpha_{0}+\alpha_{1} W D_{i, t}+\alpha_{2} I N F_{i, t}+\alpha^{*}{ }_{3} F I S_{i, t}+\alpha^{*}{ }_{6} I R P_{i, t} & \text { at } t>=t^{*}
\end{array}
$$

One simple test for this proposition is a test of structural break at $t^{*}$ or pooling the data for all $t$ and testing the interaction between a time dummy (for the period before and after $t^{*}$ ) and the fiscal balance and reform progress variables. There are no prior reasons

\footnotetext{
${ }^{5}$ Of the nine EBRD indexes of reform, Fischer and Sahay (2000) concluded that EBSM and EBLIB are the significant determinants of economic growth.

${ }^{6}$ A preliminary regression analysis using this bivariate specification yields a coefficient estimate (0.62) similar to Sachs' (1996) and significant at the 1 percent level.
} 
for preferring one year over another for setting the structural break. As a rough approximation, we use the midpoint (1998), to give us roughly the same sample size for the two sub-samples. The years through 1998 also correspond roughly to the "early transition period" which includes the years of the output decline across most of transition economies.

An additional dimension of time-varying effects of determinants of growth is the lagged impact of these variables. Using equation (2), but allowing for a lagged impact of structural reforms on economic growth, gives us:

$$
G r_{i, t}=\beta_{0}+\beta_{1} W D_{i, t}+\beta_{2} I N F_{i, t}+\beta_{3} F I S_{i, t}+\beta_{6} I R P_{i, t}+\beta_{7} I R P_{i, t-1}+\beta_{8} I R P_{i, t-1}
$$

The specification of the overall index of reform in Equation (4) follows that of Selowsky and Martin (1997) and Havrylyshyn and van Rooden (2003). This is based on the idea that the impact of policy reform may be spread over time. In addition, previous empirical studies have suggested that the contemporaneous effects may be negative due to adjustment costs, but may be compensated by subsequent positive effects. ${ }^{7}$

Are there nonlinearities due to governance and institutional quality? Data on governance measures are still only available for a limited period. They also have limited variance over time, limiting their usefulness for panel data analysis. Nonetheless, we can still use available indicators to examine how governance affects the relationship between economic growth and its key drivers. In particular, we use governance indicators to create sub-samples of countries based on their institutional quality; we then re-run the baseline regressions. We compare the coefficients estimates from the two sets of regressions and test for statistically significant differences.

Are there threshold effects? From the review of the empirical literature on growth and the size of government in the preceding section, we conclude that a new study of the size of government and growth is warranted and such a study can draw from the availability of more recent and richer data. An important advancement over the existing literature is our effort to test the common assumption of a linear relationship between size and growth and allow, instead, threshold effect in the links between expenditure and growth. We add a measure of government size to equation (2) and estimate it using a linear spline regression. ${ }^{8}$

\section{Data}

Descriptive statistics and the main data sources of the variables used in the analysis are provided in Table 1 . As explained below, most of the variables are from the data collected by World Bank (ECSPE) staff, supplemented with data from the IMF and EBRD and other specialized datasets (such as the World Bank Governance Indicator

\footnotetext{
${ }^{7}$ This is also consistent with Falcetti, Raiser, and Sanfey (2002) but they employ a simultaneous equation system.

${ }^{8}$ We can estimate a threshold model that allows either a continuous jump or a discontinuous jump. We found that the results are invariant to the specification of the threshold model.
} 
database). About 25 countries are covered in the analysis over the period 1992 to 2004, depending on the data source.

Data on real GDP growth rate $(G R)$ are from national authorities and World Bank staff estimates. Because there are notable outliers in the dataset (in particular, the summary statistics indicate minimum and maximum values corresponding to -44 percent and +81 percent, respectively), we also use data from the IMF's World Economic Outlook (WEO) database. There are fewer observations from the IMF-WEO but the range of values is also much narrower (and likely more plausible). As will be shown below, however, the results are largely invariant to data source. Data on inflation are calculated from CPI data drawn from the IMF-WEO database.

The index of armed conflict or war dummy is constructed using information from two sources: (i) Armed Conflict Events Data, following the work of Staehr (2003); and (ii) the Uppsala Armed Conflict dataset. ${ }^{9}$ The dummy takes on a value of [1] during years of conflict and [0] otherwise. Data on fiscal balance and public investment in percent of GDP are from Bank staff estimates. As an alternative, we also use data on fiscal balance from the EBRD. The indexes of reform are from de Melo et al (1996) and from the EBRD as indicated.

Our measure of government effectiveness is based on the World Bank's Governance Indicator database (see also the Data Appendix). In particular, the "government effectiveness" measure, which purports to measure "the competence of the bureaucracy and the quality of public service delivery” (Kaufmann, Kraay, and Mastruzzi 2005). An alternative measure of government effectiveness weights the level indicator by its standard error, to place greater weight on indexes whose values have narrower variations (and are thus more consistent across their survey sources). We also use a few other proxies for governance. For example, we use data on bribes in percent of annual sales drawn from the Business Environment and Enterprise Performance Survey (BEEPS). We also use data on quality of public sector institutions from the World Bank's Country Policy and Institutional Assessment (CPIA); in particular, we use the overall rating for Public Sector Management and Institutions.

There are two well-known constraints by the empirical literature on growth in transition economies, and this paper is not an exception. The first is the use of official GDP data, despite unofficial economic activity that is perceived to be significant. The second is the relatively short time span covered by these studies, and thus preventing the use of more sophisticated, dynamic specification. Nonetheless, the data used in this note represent significant improvements over the existing literature, in terms of both quantity and quality. First, while the total number of observations varies according to the regression specification, some 25 countries are now covered over a 12-year period yielding a total sample size of up to 300 observations - about double the number of observations used in some of the first empirical studies. Second, many of the data series

\footnotetext{
${ }^{9}$ Downloaded from www.onwar.com/aced/index.htm and http://www.pcr.uu.se/research/UCDP/our_data1.htm respectively.
} 
Table 1. Descriptive Statistics

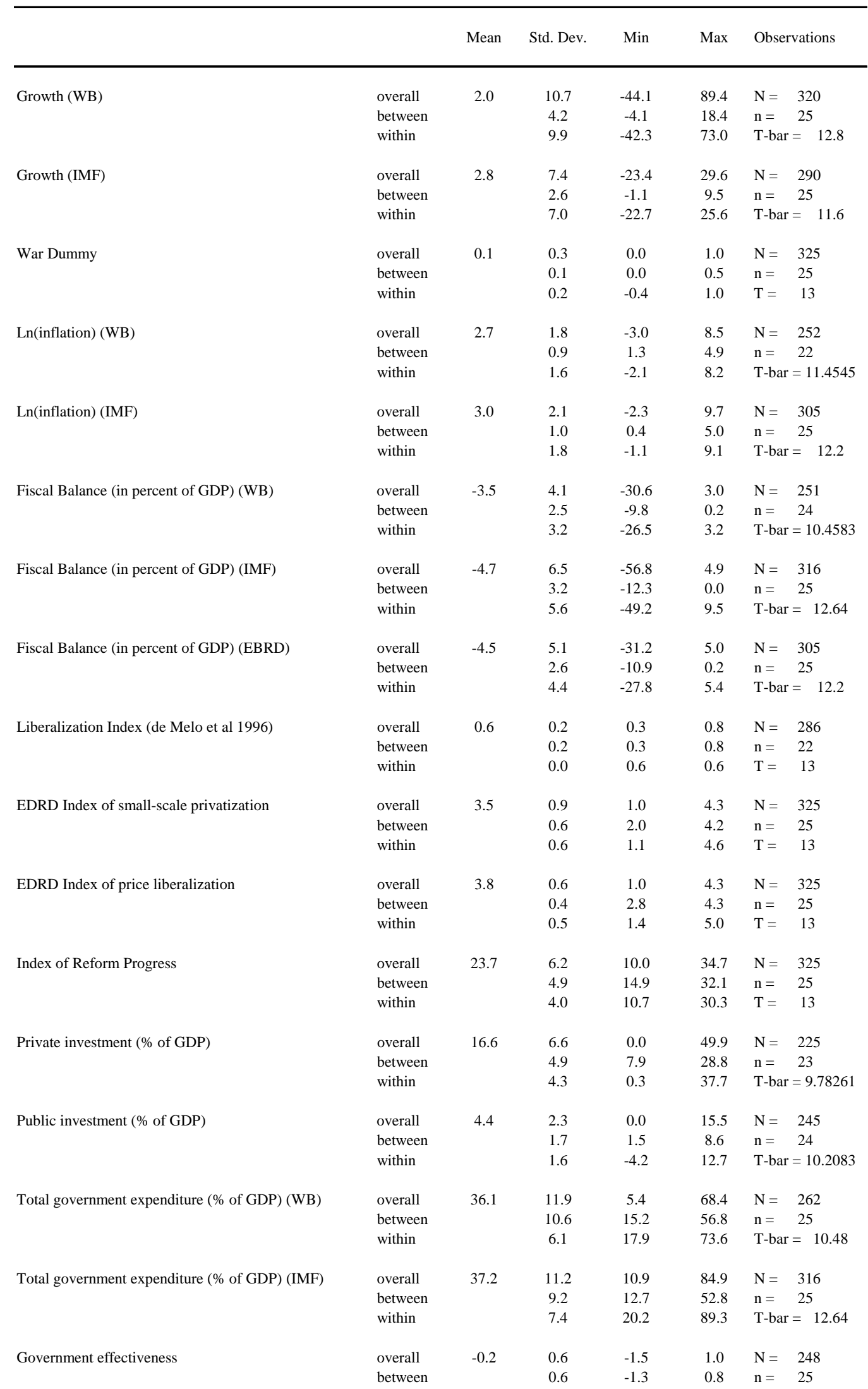


have undergone backward revisions over time, representing some improvement in quality.

The next section presents the main results of our analysis. A large, additional set of analyses based on variations on the specifications presented in the next section yield basically the same results. These results, summarized in some 36 different tables are available on request from the authors.

\section{Main Results and Discussion}

\section{A. Baseline Results and Some Simple Extensions}

Table 2 presents the main results from the baseline regression analysis. In this and in other Tables in the main text, our choice of variable has in part been determined by the resulting total number of observations. For example, because fiscal balances data from the IMF-WEO yield the most number of observations, we use this data source rather than the WB data or EBRD data. The results however are invariant to data source, as is clear from the Appendix Tables. In addition, where data on a particular variable can be drawn from several sources, data from these sources are typically closely correlated, with correlation coefficients of 0.92 or higher. In the case of inflation, for example, data from the IMF-WEO and from WB have a correlation coefficient of 0.92. Data on total government expenditure are much less similar, though the correlation coefficients are still relatively high, over 0.70 .

The results in Table 2 confirm the broad findings from the previous literature, namely, initial conditions, macroeconomic stabilization, and liberalization and structural reform all matter for growth and are in the expected direction. The second measure of structural reform, price liberalization, is however, not significant. The explanatory power of the baseline model is broadly comparable with earlier finding, with R-squares of 0.50 to 0.59 . The main results are robust to estimation methods, representing an improvement over the previous literature which relied heavily on simple OLS regressions (e.g., Sachs 1996; Fischer and Sahay 2000). One important new result is the robustness of fiscal balance as a positive determinant of growth. It may be recalled from Section 2 that the existing literature has yielded a mixed record on the importance of fiscal consolidation. 
Table 2. Determinants of Economic Growth, 1992-2004

\begin{tabular}{|c|c|c|c|c|c|c|}
\hline & $\begin{array}{l}\text { OLS } \\
(1)\end{array}$ & $\begin{array}{l}\text { Fixed Effects } \\
\text { (2) }\end{array}$ & $\begin{array}{l}\text { Random Effects } \\
\text { (3) }\end{array}$ & $\begin{array}{l}\text { OLS } \\
(4)\end{array}$ & $\begin{array}{l}\text { Fixed Effects } \\
\text { (5) }\end{array}$ & $\begin{array}{c}\text { Random Effects } \\
\text { (6) }\end{array}$ \\
\hline War dummy & $\begin{array}{l}-4.11 \\
(1.52)\end{array}$ & $\begin{array}{c}-5.34 * * * \\
(2.83)\end{array}$ & $\begin{array}{c}-4.51^{* *} \\
(2.50)\end{array}$ & $\begin{array}{l}-4.51 \\
(1.60)\end{array}$ & $\begin{array}{c}-5.17 * * * \\
(2.64)\end{array}$ & $\begin{array}{c}-4.73^{* * *} \\
(2.58)\end{array}$ \\
\hline Ln(inflation) (IMF) & $\begin{array}{c}-1.95 * * * \\
(5.56)\end{array}$ & $\begin{array}{c}-1.12 * * * \\
(3.35)\end{array}$ & $\begin{array}{c}-1.72 * * * \\
(5.81)\end{array}$ & $\begin{array}{c}-2.33^{* * *} \\
(6.97)\end{array}$ & $\begin{array}{c}-1.60 * * * \\
(4.14)\end{array}$ & $\begin{array}{l}-2.20 * * * \\
(7.24)\end{array}$ \\
\hline Fiscal balance (\%GDP) (IMF) & $\begin{array}{l}0.37 * * \\
(2.54)\end{array}$ & $\begin{array}{c}0.39 * * * \\
(5.03)\end{array}$ & $\begin{array}{c}0.40 * * * \\
(5.57)\end{array}$ & $\begin{array}{l}0.38 * * \\
(2.55)\end{array}$ & $\begin{array}{c}0.46^{* * *} \\
(5.89)\end{array}$ & $\begin{array}{c}0.43^{* * *} \\
(5.88)\end{array}$ \\
\hline EDRD Index of small-scale privatization & $\begin{array}{l}1.38 * \\
(1.82)\end{array}$ & $\begin{array}{c}4.83^{* * *} \\
(5.11)\end{array}$ & $\begin{array}{c}2.42^{* * *} \\
(3.22)\end{array}$ & & & \\
\hline EDRD Index of price liberalization & $\begin{array}{l}-0.58 \\
(0.41)\end{array}$ & $\begin{array}{c}-0.34 \\
(0.34)\end{array}$ & $\begin{array}{l}-0.62 \\
(0.65)\end{array}$ & & & \\
\hline Index of Reform Progress & & & & $\begin{array}{c}-0.04 \\
(0.34)\end{array}$ & $\begin{array}{c}0.39 * * \\
(2.19)\end{array}$ & $\begin{array}{c}0.04 \\
(0.34)\end{array}$ \\
\hline Constant & $\begin{array}{c}6.85 \\
(1.11)\end{array}$ & $\begin{array}{l}-8.42 \\
(1.57)\end{array}$ & $\begin{array}{c}2.95 \\
(0.67)\end{array}$ & $\begin{array}{c}11.60^{* * *} \\
(3.00)\end{array}$ & $\begin{array}{l}-0.47 \\
(0.09)\end{array}$ & $\begin{array}{c}9.57 * * * \\
(2.76)\end{array}$ \\
\hline $\begin{array}{l}\text { Observations } \\
\text { R-squared }\end{array}$ & $\begin{array}{l}305 \\
0.51\end{array}$ & $\begin{array}{l}305 \\
0.59\end{array}$ & 305 & $\begin{array}{c}305 \\
0.5\end{array}$ & $\begin{array}{l}305 \\
0.56\end{array}$ & 305 \\
\hline Number of countries & & 25 & 25 & & 25 & 25 \\
\hline
\end{tabular}

Robust t statistics in parentheses. Dependent variable is Economic Growth (WB)

* significant at $10 \%$; ** significant at $5 \%$; *** significant at $1 \%$

The baseline results appear to be robust to various specifications. For example, the IRP reform measure can be used in place of the EBRD reform indexes. The results, based on equation (2) and presented in columns 4 to 6 of Table 2 are similar to those in columns 1 to 3, although IRP itself does not appear to be consistently significant. IRP has a significant effect using a fixed effects estimator, but not for OLS nor for random effects. The impact of fiscal balance, however, is consistent and robust, and so are the war dummy and inflation.

We also test the results for the inclusion of an alternative measure of initial conditions - initial income per capita in 1992, a measure of initial conditions typically used in the broader literature on growth but not in literature on transition economies, possibly because data for early transition period are more likely to be measured with error. The results (not shown) using OLS and Random Effects regression method remain consistent with the baseline results. With respect to initial income, the results suggest some convergence over time: economies with higher per capita income in 1992 grew more slowly thereafter.

\section{B. Time-Varying Effects}

We begin this section with two observations from the previous section. First, while the impact of fiscal balance has been mixed in the previous literature, we are able to provide relatively more robust evidence that fiscal balance matters for growth. Second, Sachs (1996) provides evidence that IRP is a strongly significant determinant of economic growth although we are unable to provide robust confirmation. Consistent with the discussion in Section 2, these two observations may be explained in part by the continually evolving relative importance of the main determinants of growth in transition economies. That is, overall reform progress may have been important during the first 
decade of transition, but less so during the latter stages, as reform programs have advanced in many of the transition economies. ${ }^{10}$ In 1995, only one country had an IRP above 30 (Hungary); in 2005, ten countries have IRPs above this threshold. The shifting relative importance of drivers of growth may also help explain why the early literature transition economy growth did not yield consistent findings on the importance of fiscal balance yet in our baseline results the positive impact of fiscal balance on economic growth is unambiguous and robust.

The results are presented in Table 3 and provide some evidence of the timevarying impact of fiscal balance and reform progress. The results under column (2), for example, based on fixed effects, imply that the net impact of fiscal balance on economic growth through 1998 is about 0.36 and more than double at 0.77 thereafter. As for IRP, its net impact on growth is 0.50 through 1998, and not statistically different from 0 thereafter.

Table 3. Determinants of Economic Growth, 1992-2004: Accounting for Time-Varying Effects

\begin{tabular}{|c|c|c|c|c|c|c|}
\hline & $\begin{array}{l}\text { OLS } \\
(1)\end{array}$ & $\begin{array}{c}\text { Fixed Effects } \\
\text { (2) }\end{array}$ & $\begin{array}{c}\text { Random Effects } \\
\text { (3) }\end{array}$ & $\begin{array}{l}\text { OLS } \\
(4)\end{array}$ & $\begin{array}{c}\text { Fixed Effects } \\
\text { (5) }\end{array}$ & $\begin{array}{c}\text { Random Effects } \\
\text { (6) }\end{array}$ \\
\hline War dummy & $\begin{array}{l}-4.18 \\
(1.43)\end{array}$ & $\begin{array}{c}-5.33 * * * \\
(2.75)\end{array}$ & $\begin{array}{c}-4.65^{* * *} \\
(2.60)\end{array}$ & $\begin{array}{l}-4.51 \\
(1.64)\end{array}$ & $\begin{array}{c}-7.20 * * * \\
(3.76)\end{array}$ & $\begin{array}{c}-4.51 * * * \\
(2.70)\end{array}$ \\
\hline Ln(inflation) (IMF) & $\begin{array}{c}-1.89 * * * \\
(4.39)\end{array}$ & $\begin{array}{c}-1.47^{* * * *} \\
(3.77)\end{array}$ & $\begin{array}{c}-1.83^{* * * *} \\
(5.59)\end{array}$ & $\begin{array}{c}-1.65^{* * * *} \\
(4.18)\end{array}$ & $\begin{array}{c}-1.71^{* * * *} \\
(4.30)\end{array}$ & $\begin{array}{c}-1.65^{* * *} \\
(4.97)\end{array}$ \\
\hline Fiscal balance (\%GDP) (IMF) & $\begin{array}{c}0.57^{* * *} \\
(6.02)\end{array}$ & $\begin{array}{c}0.77 * * * \\
(3.79)\end{array}$ & $\begin{array}{c}0.65^{* * *} \\
(3.48)\end{array}$ & $\begin{array}{c}0.44^{* * *} \\
(4.27)\end{array}$ & $\begin{array}{c}0.75^{* * *} \\
(3.58)\end{array}$ & $\begin{array}{c}0.44^{* *} \\
(2.36)\end{array}$ \\
\hline Fiscal balance (\%GDP) * Dummy (years through 1998) & $\begin{array}{c}-0.3 \\
(1.59)\end{array}$ & $\begin{array}{l}-0.41^{*} \\
(1.94)\end{array}$ & $\begin{array}{l}-0.35^{*} \\
(1.74)\end{array}$ & $\begin{array}{l}-0.21 \\
(1.20)\end{array}$ & $\begin{array}{c}-0.44 * * \\
(2.00)\end{array}$ & $\begin{array}{l}-0.21 \\
(1.04)\end{array}$ \\
\hline Index of Reform Progress & $\begin{array}{c}-0.33^{* *} \\
(2.24)\end{array}$ & $\begin{array}{c}0.09 \\
(0.40)\end{array}$ & $\begin{array}{c}-0.27 * * \\
(2.04)\end{array}$ & $\begin{array}{c}-0.33^{* *} \\
(2.47)\end{array}$ & $\begin{array}{c}-0.88^{* * *} \\
(3.21)\end{array}$ & $\begin{array}{c}-0.33^{* * *} \\
(2.92)\end{array}$ \\
\hline Index of Reform Progress * Dummy (years through 1998) & $\begin{array}{c}0.66 * * * \\
(3.04)\end{array}$ & $\begin{array}{c}0.50 * * * \\
(3.18)\end{array}$ & $\begin{array}{c}0.62 * * * \\
(4.11)\end{array}$ & $\begin{array}{l}0.45 * * \\
(2.17)\end{array}$ & $\begin{array}{c}0.39 * * \\
(2.53)\end{array}$ & $\begin{array}{c}0.45^{* * *} \\
(2.93)\end{array}$ \\
\hline Constant & $\begin{array}{c}19.39 * * * \\
(4.36)\end{array}$ & $\begin{array}{c}8.06 \\
(1.32)\end{array}$ & $\begin{array}{c}17.89 * * * \\
(4.76)\end{array}$ & $\begin{array}{c}5.32 \\
(0.94)\end{array}$ & $\begin{array}{c}7.77 \\
(1.37)\end{array}$ & $\begin{array}{c}5.32 \\
(1.36)\end{array}$ \\
\hline $\begin{array}{l}\text { Observations } \\
\text { R-squared }\end{array}$ & $\begin{array}{l}305 \\
0.54\end{array}$ & $\begin{array}{l}305 \\
0.58\end{array}$ & 305 & $\begin{array}{l}305 \\
0.6\end{array}$ & $\begin{array}{l}305 \\
0.64\end{array}$ & 305 \\
\hline Number of countries & & 25 & 25 & & 25 & 25 \\
\hline
\end{tabular}

Robust t statistics in parentheses

* significant at $10 \%$; ** significant at $5 \%$; *** significant at $1 \%$

\section{Lagged Effects}

Using equation (4), we can re-run the baseline regressions but allowing for the lagged impact of reform progress. The results are presented in Table 4 and suggest negative contemporaneous effects (though insignificant) and lagged positive effects from

\footnotetext{
${ }^{10}$ This may also explain, in part, why Godoy and Stiglitz (2006) why, using more recent data, some variables which thought to "play a large role in the earlier literature, appear to have at most a marginal effect.”
} 
policy reform (after two period, through 1998), broadly consistent with the existing literature. These cumulative effects are less perceptible in recent years, as expected. ${ }^{11}$

Table 4. Determinants of Economic Growth, 1992-2004: Lagged Effects and Time-Varying Impact

\begin{tabular}{|c|c|c|c|c|c|c|c|c|c|}
\hline & \multicolumn{3}{|c|}{ All } & \multicolumn{3}{|c|}{ Through 1998} & \multicolumn{3}{|c|}{1999 Onwards } \\
\hline & $\begin{array}{l}\text { OLS } \\
\text { (1) }\end{array}$ & $\begin{array}{l}\text { Fixed Effects } \\
\text { (2) }\end{array}$ & $\begin{array}{l}\text { Random Effects } \\
\text { (3) }\end{array}$ & $\begin{array}{l}\text { OLS } \\
\text { (4) }\end{array}$ & $\begin{array}{l}\text { Fixed Effects } \\
\text { (5) }\end{array}$ & $\begin{array}{c}\text { Random Effects } \\
\text { (6) }\end{array}$ & $\begin{array}{l}\text { OLS } \\
(7)\end{array}$ & $\begin{array}{l}\text { Fixed Effects } \\
\text { (8) }\end{array}$ & $\begin{array}{c}\text { Random Effects } \\
\text { (9) }\end{array}$ \\
\hline War dummy & $\begin{array}{l}-2.49 \\
(0.68)\end{array}$ & $\begin{array}{c}-4.60 * * \\
(2.15)\end{array}$ & $\begin{array}{c}-3.1 \\
(1.55)\end{array}$ & $\begin{array}{c}3.41 \\
(0.90)\end{array}$ & $\begin{array}{c}1.45 \\
(0.49)\end{array}$ & $\begin{array}{c}1.52 \\
(0.58)\end{array}$ & $\begin{array}{c}-18.39 * * * \\
(2.80)\end{array}$ & $\begin{array}{c}-20.30 * * * \\
(6.24)\end{array}$ & $\begin{array}{c}-18.58 * * * \\
(6.66)\end{array}$ \\
\hline Ln(inflation) & $\begin{array}{c}-1.70^{* * *} \\
(4.71)\end{array}$ & $\begin{array}{c}-1.44 * * * \\
(3.39)\end{array}$ & $\begin{array}{c}-1.62^{* * *} \\
(5.15)\end{array}$ & $\begin{array}{c}-3.24^{* * *} \\
(4.47)\end{array}$ & $\begin{array}{c}-3.24 * * * \\
(4.54)\end{array}$ & $\begin{array}{c}-3.32 * * * \\
(5.80)\end{array}$ & $\begin{array}{l}-0.29 \\
(1.07)\end{array}$ & $\begin{array}{c}-0.08 \\
(0.18)\end{array}$ & $\begin{array}{l}-0.29 \\
(0.98)\end{array}$ \\
\hline Fiscal balance (\%GDP) (IMF) & $\begin{array}{l}0.46 * * * \\
(3.53)\end{array}$ & $\begin{array}{l}0.78^{* * *} \\
(5.94)\end{array}$ & $\begin{array}{l}0.55^{* * *} \\
(4.92)\end{array}$ & $\begin{array}{c}0.16 \\
(0.79)\end{array}$ & $\begin{array}{l}0.49^{*} \\
(1.86)\end{array}$ & $\begin{array}{l}0.36^{*} \\
(1.66)\end{array}$ & $\begin{array}{c}0.49 * * * \\
(6.39)\end{array}$ & $\begin{array}{c}0.58^{* * *} \\
(3.35)\end{array}$ & $\begin{array}{c}0.49 * * * \\
(4.44)\end{array}$ \\
\hline Overall index of reform (t) & $\begin{array}{l}-0.31 \\
(0.65)\end{array}$ & $\begin{array}{l}-0.70^{*} \\
(1.77)\end{array}$ & $\begin{array}{l}-0.38 \\
(1.12)\end{array}$ & $\begin{array}{c}0.17 \\
(0.32)\end{array}$ & $\begin{array}{l}-0.42 \\
(0.84)\end{array}$ & $\begin{array}{l}-0.15 \\
(0.38)\end{array}$ & $\begin{array}{l}-0.77^{*} \\
(1.74)\end{array}$ & $\begin{array}{l}-1.48^{* *} \\
(2.07)\end{array}$ & $\begin{array}{c}-0.84 \\
(1.43)\end{array}$ \\
\hline Overall index of reform (t-1) & $\begin{array}{c}-0.2 \\
(0.35)\end{array}$ & $\begin{array}{l}-0.03 \\
(0.06)\end{array}$ & $\begin{array}{l}-0.15 \\
(0.32)\end{array}$ & $\begin{array}{l}-0.57 \\
(0.92)\end{array}$ & $\begin{array}{l}-0.64 \\
(1.20)\end{array}$ & $\begin{array}{l}-0.67 \\
(1.33)\end{array}$ & $\begin{array}{c}0.54 \\
(0.94)\end{array}$ & $\begin{array}{l}1.05 \\
(1.24)\end{array}$ & $\begin{array}{c}0.6 \\
(0.75)\end{array}$ \\
\hline Overall index of reform (t-2) & $\begin{array}{l}0.39 \\
(1.49)\end{array}$ & $\begin{array}{l}0.44^{*} \\
(1.67)\end{array}$ & $\begin{array}{l}0.40 \\
(1.50)\end{array}$ & $\begin{array}{l}0.38 \\
(1.19)\end{array}$ & $\begin{array}{l}0.58^{*} \\
(1.85)\end{array}$ & $\begin{array}{l}0.51^{*} \\
(1.68)\end{array}$ & $\begin{array}{l}0.00 \\
(0.01)\end{array}$ & $\begin{array}{l}0.09 \\
(0.18)\end{array}$ & $\begin{array}{l}0.02 \\
(0.04)\end{array}$ \\
\hline Constant & $\begin{array}{c}13.39 * * * \\
(3.53)\end{array}$ & $\begin{array}{c}18.57 * * * \\
(2.85)\end{array}$ & $\begin{array}{c}13.97 * * * \\
(4.42)\end{array}$ & $\begin{array}{l}13.85^{*} \\
(1.71)\end{array}$ & $\begin{array}{c}26.89 * * \\
(2.50)\end{array}$ & $\begin{array}{c}22.63^{* * *} \\
(3.36)\end{array}$ & $\begin{array}{c}13.88^{* * *} \\
(4.17)\end{array}$ & $\begin{array}{l}17.49 * \\
(1.88)\end{array}$ & $\begin{array}{c}14.00^{* * *} \\
(5.76)\end{array}$ \\
\hline Observations & 259 & 259 & 259 & 115 & 115 & 115 & 144 & 144 & 144 \\
\hline R-squared & 0.31 & 0.39 & & 0.39 & 0.47 & & 0.35 & 0.33 & \\
\hline Number of countries & & 25 & 25 & & 25 & 25 & & 25 & 25 \\
\hline
\end{tabular}

Robust $\mathrm{t}$ statistics in parentheses

* significant at $10 \%$; ** significant at $5 \%$; *** significant at $1 \%$

What is notable is that fiscal balance is consistently a strong positive determinant of economic growth, regardless of the lag structure, and particularly in recent period. Inflation, as a measure of macroeconomic stability is also a significant determinant, but less so in more recent years.

\section{Institutional Quality \& Size of Government}

Does governance matter for economic growth? Unfortunately, available data on governance indicators are still insufficient to fully exploit the panel data on growth and its key determinants. Data from the Governance Indicators database cover only the latter half of our panel dataset, while BEEPS data cover only a couple of years.

Notwithstanding these data difficulties, we use two measures of governancegovernment effectiveness and quality of public sector management and institutions from the Governance Indicators and CPIA databases, respectively-to create sub-samples of countries with relatively lower, and relatively higher, governance (median) scores. We then re-run the baseline model using these sub-samples.

In addition, we test more formally for the existence of a statistical relationship between size of government and growth following the discussion in Section 2. We also

\footnotetext{
${ }^{11}$ There are some variables that may affect both the evolution of reforms and economic growth. Dethier and others (1999) for example suggest that democracy may help promote market liberalization. To the extent that political freedom and civil liberties are also related to growth, these interrelationships need to be more fully accounted for.
} 
allow for threshold effects. The results, accounting for both institutional quality and size of government, are presented in Tables 5 and 6.

Table 5. Economic Growth and the Size of Government

By Government Effectiveness (WB Governance Indicator for Government Effectiveness)

\begin{tabular}{|c|c|c|c|c|c|c|c|c|c|}
\hline & \multicolumn{3}{|c|}{ All Countries } & \multicolumn{3}{|c|}{ Relatively More Effective Government } & \multicolumn{3}{|c|}{ Relatively Less Effective Government } \\
\hline & $\begin{array}{l}\text { OLS } \\
\text { (1) }\end{array}$ & $\begin{array}{l}\text { Fixed Effects } \\
\text { (2) }\end{array}$ & $\begin{array}{c}\text { Random Effects } \\
\text { (3) }\end{array}$ & $\begin{array}{c}\text { OLS } \\
(1)\end{array}$ & $\begin{array}{l}\text { Fixed Effects } \\
\text { (2) }\end{array}$ & $\begin{array}{c}\text { Random Effects } \\
\text { (3) }\end{array}$ & $\begin{array}{c}\text { OLS } \\
(1)\end{array}$ & $\begin{array}{l}\text { Fixed Effects } \\
\text { (2) }\end{array}$ & $\begin{array}{c}\text { Random Effects } \\
\text { (3) }\end{array}$ \\
\hline War dummy & $\begin{array}{l}-5.45^{*} \\
(1.86)\end{array}$ & $\begin{array}{c}-5.92 * * * \\
(3.18)\end{array}$ & $\begin{array}{c}-5.67 * * * \\
(3.27)\end{array}$ & $\begin{array}{l}-3.16 \\
(1.55)\end{array}$ & $\begin{array}{l}-1.69 \\
(0.89)\end{array}$ & $\begin{array}{l}-2.66^{*} \\
(1.66)\end{array}$ & $\begin{array}{c}-5.74 \\
(1.25)\end{array}$ & $\begin{array}{c}-4.7 \\
(1.48)\end{array}$ & $\begin{array}{l}-5.34^{*} \\
(1.81)\end{array}$ \\
\hline Ln(inflation) (IMF) & $\begin{array}{c}-1.91 * * * \\
(5.95)\end{array}$ & $\begin{array}{c}-1.83^{* * *} \\
(5.32)\end{array}$ & $\begin{array}{c}-1.85 * * * \\
(6.30)\end{array}$ & $\begin{array}{c}-0.88^{* * *} \\
(3.37)\end{array}$ & $\begin{array}{c}-1.06 * * * \\
(3.89)\end{array}$ & $\begin{array}{c}-1.00 * * * \\
(4.18)\end{array}$ & $\begin{array}{c}-2.97 * * * \\
(4.80)\end{array}$ & $\begin{array}{c}-2.38^{* * *} \\
(3.43)\end{array}$ & $\begin{array}{c}-2.72 * * * \\
(4.48)\end{array}$ \\
\hline Fiscal balance (\%GDP) (EBRD) & $\begin{array}{c}0.51^{* * *} \\
(4.75)\end{array}$ & $\begin{array}{l}0.38 * * * \\
(3.24)\end{array}$ & $\begin{array}{c}0.49 * * * \\
(5.22)\end{array}$ & $\begin{array}{c}0.71^{* * * *} \\
(7.20)\end{array}$ & $\begin{array}{c}0.73^{* * * *} \\
(6.31)\end{array}$ & $\begin{array}{c}0.70^{* * *} \\
(7.01)\end{array}$ & $\begin{array}{c}0.47^{* * *} \\
(3.38)\end{array}$ & $\begin{array}{c}0.32 \\
(1.64)\end{array}$ & $\begin{array}{c}0.44 * * * \\
(2.83)\end{array}$ \\
\hline Overall index of reform & $\begin{array}{l}-0.01 \\
(0.08)\end{array}$ & $\begin{array}{l}-0.11 \\
(0.68)\end{array}$ & $\begin{array}{l}-0.05 \\
(0.40)\end{array}$ & $\begin{array}{c}0.34^{* * *} \\
(3.94)\end{array}$ & $\begin{array}{c}0.36^{* * *} \\
(2.90)\end{array}$ & $\begin{array}{c}0.34^{* * *} \\
(3.49)\end{array}$ & $\begin{array}{l}-0.59^{*} \\
(1.66)\end{array}$ & $\begin{array}{l}-0.52 \\
(1.41)\end{array}$ & $\begin{array}{c}-0.62 * * \\
(1.99)\end{array}$ \\
\hline Expenditure (in percent of GDP) $(<35 \%)$ & $\begin{array}{l}-0.14 \\
(1.26)\end{array}$ & $\begin{array}{l}-0.25 \\
(1.65)\end{array}$ & $\begin{array}{l}-0.17^{*} \\
(1.67)\end{array}$ & $\begin{array}{l}-0.08 \\
(0.15)\end{array}$ & $\begin{array}{l}-0.11 \\
(0.27)\end{array}$ & $\begin{array}{l}-0.12 \\
(0.29)\end{array}$ & $\begin{array}{c}0.00 \\
(0.00)\end{array}$ & $\begin{array}{c}-0.2 \\
(0.85)\end{array}$ & $\begin{array}{l}-0.08 \\
(0.45)\end{array}$ \\
\hline Expenditure (in percent of GDP) (>=35\%. & $\begin{array}{l}-0.13^{*} \\
(1.68)\end{array}$ & $\begin{array}{c}-0.41^{* * *} \\
(3.85)\end{array}$ & $\begin{array}{c}-0.26 * * * \\
(2.87)\end{array}$ & $\begin{array}{l}0.13 * * \\
(2.16)\end{array}$ & $\begin{array}{l}0.19^{*} \\
(1.74)\end{array}$ & $\begin{array}{l}0.14^{*} \\
(1.84)\end{array}$ & $\begin{array}{c}-0.48 * * * \\
(2.87)\end{array}$ & $\begin{array}{c}-0.67 * * * \\
(3.60)\end{array}$ & $\begin{array}{c}-0.55^{* * *} \\
(3.36)\end{array}$ \\
\hline Dummy (Expenditure >=35\%) & $\begin{array}{l}-0.52 \\
(0.43)\end{array}$ & $\begin{array}{c}0.12 \\
(0.09)\end{array}$ & $\begin{array}{c}0.09 \\
(0.08)\end{array}$ & $\begin{array}{l}-1.18 \\
(0.88)\end{array}$ & $\begin{array}{l}-0.62 \\
(0.60)\end{array}$ & $\begin{array}{l}-0.81 \\
(0.82)\end{array}$ & $\begin{array}{c}0.08 \\
(0.03)\end{array}$ & $\begin{array}{l}-0.93 \\
(0.30)\end{array}$ & $\begin{array}{l}-0.45 \\
(0.15)\end{array}$ \\
\hline Constant & $\begin{array}{c}16.10^{* * *} \\
(3.42)\end{array}$ & $\begin{array}{c}22.29 * * * \\
(3.34)\end{array}$ & $\begin{array}{c}18.14 * * * \\
(4.41)\end{array}$ & $\begin{array}{c}0.8 \\
(0.04)\end{array}$ & $\begin{array}{c}0.96 \\
(0.07)\end{array}$ & $\begin{array}{c}2.13 \\
(0.16)\end{array}$ & $\begin{array}{c}28.71^{* * *} \\
(2.66)\end{array}$ & $\begin{array}{c}31.18^{* * *} \\
(2.71)\end{array}$ & $\begin{array}{c}31.43^{* * *} \\
(3.41)\end{array}$ \\
\hline Observations & 295 & 295 & 295 & 160 & 160 & 160 & 135 & 135 & 135 \\
\hline R-squared & 0.56 & 0.6 & & 0.61 & 0.61 & & 0.6 & 0.63 & \\
\hline Number of countries & & 25 & 25 & & 13 & 13 & & 12 & 12 \\
\hline
\end{tabular}

Robust t statistics in parentheses

* significant at $10 \%$;* significant at $5 \%$;** significant at $1 \%$

The results suggest the following: First, the impact of the size of government on economic growth is nonlinear. We experimented with plausible threshold values given the sample characteristics. We settled on a threshold value of 35 percent of GDP, which is roughly equal to the sample median and mean values and also yielded the strongest results. ${ }^{12}$ The results in Table 1 provide strong evidence that at expenditure levels of 35 percent of GDP or higher, public spending negatively affects growth. At levels below 35 percent, public sector size has no robust measurable effect on growth (see also Figure 2).

Figure 2: Size of Government and Economic Growth: Threshold Effects

\footnotetext{
${ }^{12}$ Threshold estimation procedures developed by Hansen (2000) using our data set were performed by Emilia Skrok and yielded a similar threshold (34 percent of GDP). This contribution to the analysis is gratefully acknowledged.
} 


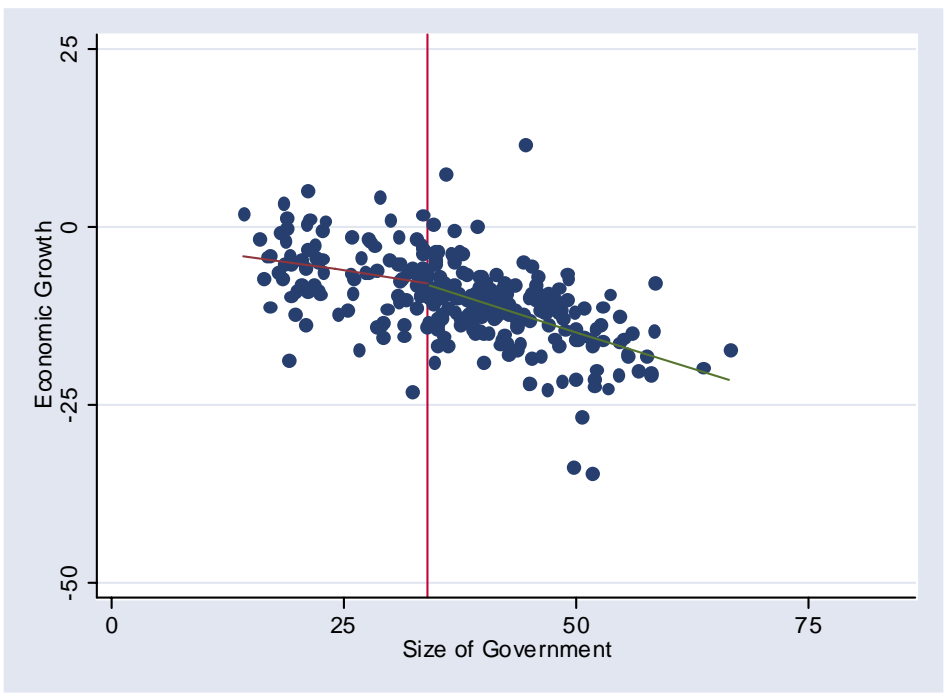

The impact of the size of government on economic growth is likely to be nonlinear for several reasons. First, while small governments tend to concentrate spending on the provision of key public goods (rule of law, defense, infrastructure) and efficiency-improving services (education, health care), large governments tend to spend more on "unproductive" core government functions, social transfers, and subsidies that are not conducive to growth (discussed further below). Second, limited administrative capacity could be another reason why a threshold may exist in the way public spending affects growth. Administrative capacity improves only slowly, reflecting gradual improvements in public sector management and civil servant skills, yet expenditure programs may grow relatively swiftly, resulting in administrative bottlenecks, poor program design, and low expenditure effectiveness. Third, financing of big governments requires high levels of taxation that are likely to distort incentives for saving, investment, and work effort beyond some threshold level. ${ }^{13}$ The general rule of thumb is that deadweight losses from taxes increase in proportion to the square of taxation.

It may be argued that, regardless of whether the relationship between size of government and growth is nonlinear or not, the strong negative relationship between growth and the size of government at higher levels of expenditure may be an artifact of the data and thus driven by outliers. In particular, in the early transition period, the sample consisted of very large governments in countries experiencing a deep recession. From the mid-1990s, onward, the size of government, on average, is lower and much more stable, coinciding with the economic recovery. However, our further analysis indicates that restricting the sample to this period - that is, from the mid-1990s onwards-yields results that are similar to the baseline. ${ }^{14}$

\footnotetext{
${ }^{13}$ Regarding, for example, the decision to work, it is expected that an increase in income taxation will discourage labor supply (at least in the formal sector) when a point is reached where substitution effects that favor more leisure (which becomes less expensive in terms of foregone after-tax income) may prevail against income effects that encourage additional work effort as a result of the reduction in after-tax income. ${ }^{14}$ The results are available on request. That the baseline results are robust should not be surprising because, among other things, this exercise also effectively excludes the (early transition) period for which available data are likely to be of lower quality.
} 
There is, however, on important qualification to the relationship between size of government and growth: This relationship is likely to depend on public sector governance. In countries where public sector governance is weak, misallocations of public expenditures and weak administrative capacity are likely to be exacerbated, making the non-linear impact of large government programs more pronounced. In addition, taxes are likely to be more distortionary when governance is poor, with high compliance costs and bribery of tax officials adding to the impact of high and distorting tax rates. In contrast, the threshold effects of big governments on growth may be mitigated by strong public institutions. The quality of institutions can thus be expected to mitigate the negative impact of public sector size on growth.

Indeed, the results in Table 5 indicate that public sector size negatively affects growth, but much less so in countries with good institutions. The results are broadly consistent with regressions based on the CPIA measure of public sector quality (Table 6). In particular, focusing on the fixed effects regression results, public spending has a negative impact, while at levels below the threshold, there is no measurable impact on economic growth, but the impact is mitigated by governance. Governance also appears to mitigate the payoffs from macroeconomic stability; in particular, payoffs from macroeconomic stability seem higher in an environment characterized by good public sector institutions. The coefficient of fiscal balance, in particular, is generally measurably higher when governments are relatively more effective (Tables 5 and 6).

Table 6. Economic Growth and the Size of Government By Government Effectiveness (CPIA Indicator for Public Sector Management)

\begin{tabular}{|c|c|c|c|c|c|c|c|c|c|}
\hline & \multicolumn{3}{|c|}{ All Countries } & \multicolumn{3}{|c|}{ Relatively More Effective Government } & \multicolumn{3}{|c|}{ Relatively Less Effective Government } \\
\hline & $\begin{array}{l}\text { OLS } \\
\text { (1) }\end{array}$ & $\begin{array}{l}\text { Fixed Effects } \\
\text { (2) }\end{array}$ & $\begin{array}{c}\text { Random Effects } \\
\text { (3) }\end{array}$ & $\begin{array}{l}\text { OLS } \\
(1)\end{array}$ & $\begin{array}{l}\text { Fixed Effects } \\
\text { (2) }\end{array}$ & $\begin{array}{c}\text { Random Effects } \\
\text { (3) }\end{array}$ & $\begin{array}{l}\text { OLS } \\
(1)\end{array}$ & $\begin{array}{l}\text { Fixed Effects } \\
\text { (2) }\end{array}$ & $\begin{array}{c}\text { Random Effects } \\
\text { (3) }\end{array}$ \\
\hline War dummy & $\begin{array}{l}-5.45^{*} \\
(1.86)\end{array}$ & $\begin{array}{c}-5.92 * * * \\
(3.18)\end{array}$ & $\begin{array}{c}-5.67 * * * \\
(3.27)\end{array}$ & $\begin{array}{c}4.00 \\
(1.06)\end{array}$ & $\begin{array}{l}4.79 * \\
(1.93)\end{array}$ & $\begin{array}{l}4.22^{*} \\
(1.89)\end{array}$ & $\begin{array}{c}-11.55^{* * *} \\
(4.15)\end{array}$ & $\begin{array}{c}-9.74 * * * \\
(3.81)\end{array}$ & $\begin{array}{c}-10.85^{* * *} \\
(4.49)\end{array}$ \\
\hline Ln(inflation) (IMF) & $\begin{array}{c}-1.91 * * * \\
(5.95)\end{array}$ & $\begin{array}{c}-1.83^{* * *} \\
(5.32)\end{array}$ & $\begin{array}{c}-1.85^{* * * *} \\
(6.30)\end{array}$ & $\begin{array}{c}-1.16^{* * * *} \\
(3.54)\end{array}$ & $\begin{array}{l}-0.80^{*} \\
(1.93)\end{array}$ & $\begin{array}{c}-1.11^{* * *} \\
(3.01)\end{array}$ & $\begin{array}{c}-2.51^{* * * *} \\
(5.42)\end{array}$ & $\begin{array}{c}-2.01 * * * \\
(3.79)\end{array}$ & $\begin{array}{c}-2.36 * * * \\
(5.26)\end{array}$ \\
\hline Fiscal balance (\%GDP) (EBRD) & $\begin{array}{c}0.51 * * * \\
(4.75)\end{array}$ & $\begin{array}{c}0.38^{* * * *} \\
(3.24)\end{array}$ & $\begin{array}{c}0.49^{* * *} \\
(5.22)\end{array}$ & $\begin{array}{l}0.42 * * \\
(2.41)\end{array}$ & $\begin{array}{c}0.72^{* * * *} \\
(4.68)\end{array}$ & $\begin{array}{c}0.50 * * * \\
(3.67)\end{array}$ & $\begin{array}{c}0.44^{* * *} \\
(3.90)\end{array}$ & $\begin{array}{c}0.15 \\
(0.94)\end{array}$ & $\begin{array}{c}0.37 * * * \\
(2.91)\end{array}$ \\
\hline Overall index of reform & $\begin{array}{l}-0.01 \\
(0.08)\end{array}$ & $\begin{array}{l}-0.11 \\
(0.68)\end{array}$ & $\begin{array}{l}-0.05 \\
(0.40)\end{array}$ & $\begin{array}{c}0.18 \\
(1.22)\end{array}$ & $\begin{array}{l}0.41^{* *} \\
(2.18)\end{array}$ & $\begin{array}{c}0.17 \\
(1.14)\end{array}$ & $\begin{array}{l}-0.38 \\
(1.56)\end{array}$ & $\begin{array}{c}-0.2 \\
(0.75)\end{array}$ & $\begin{array}{l}-0.33 \\
(1.47)\end{array}$ \\
\hline Expenditure (in percent of GDP) $(<35 \%)$ & $\begin{array}{l}-0.14 \\
(1.26)\end{array}$ & $\begin{array}{l}-0.25 \\
(1.65)\end{array}$ & $\begin{array}{l}-0.17^{*} \\
(1.67)\end{array}$ & $\begin{array}{c}-0.51 * * * \\
(2.80)\end{array}$ & $\begin{array}{l}-0.02 \\
(0.09)\end{array}$ & $\begin{array}{c}-0.47 * * * \\
(3.84)\end{array}$ & $\begin{array}{c}0.13 \\
(1.17)\end{array}$ & $\begin{array}{l}-0.24 \\
(1.22)\end{array}$ & $\begin{array}{l}-0.01 \\
(0.08)\end{array}$ \\
\hline Expenditure (in percent of GDP) ( $>=35 \%$. & $\begin{array}{l}-0.13^{*} \\
(1.68)\end{array}$ & $\begin{array}{c}-0.41 * * * \\
(3.85)\end{array}$ & $\begin{array}{c}-0.26 * * * \\
(2.87)\end{array}$ & $\begin{array}{c}0.03 \\
(0.39)\end{array}$ & $\begin{array}{l}0.38 * * \\
(2.27)\end{array}$ & $\begin{array}{c}0.13 \\
(1.04)\end{array}$ & $\begin{array}{c}-0.30^{* *} \\
(2.21)\end{array}$ & $\begin{array}{c}-0.57 * * * \\
(3.89)\end{array}$ & $\begin{array}{c}-0.38 * * * * \\
(3.07)\end{array}$ \\
\hline Dummy (Expenditure >=35\%) & $\begin{array}{l}-0.52 \\
(0.43)\end{array}$ & $\begin{array}{c}0.12 \\
(0.09)\end{array}$ & $\begin{array}{c}0.09 \\
(0.08)\end{array}$ & $\begin{array}{c}1.92 \\
(1.07)\end{array}$ & $\begin{array}{c}1.15 \\
(0.75)\end{array}$ & $\begin{array}{c}1.65 \\
(1.15)\end{array}$ & $\begin{array}{l}-2.49 \\
(1.50)\end{array}$ & $\begin{array}{l}-2.23 \\
(1.15)\end{array}$ & $\begin{array}{l}-2.09 \\
(1.12)\end{array}$ \\
\hline Constant & $\begin{array}{c}16.10^{* * * *} \\
(3.42)\end{array}$ & $\begin{array}{c}22.29 * * * \\
(3.34)\end{array}$ & $\begin{array}{c}18.14^{* * *} \\
(4.41)\end{array}$ & $\begin{array}{c}17.90^{* *} \\
(2.13)\end{array}$ & $\begin{array}{l}-5.55 \\
(0.61)\end{array}$ & $\begin{array}{c}16.83^{* * * *} \\
(3.54)\end{array}$ & $\begin{array}{c}19.00^{* * * *} \\
(3.19)\end{array}$ & $\begin{array}{c}24.41^{* * * *} \\
(2.64)\end{array}$ & $\begin{array}{c}21.58^{* * * *} \\
(3.05)\end{array}$ \\
\hline Observations & 295 & 295 & 295 & 152 & 152 & 152 & 143 & 143 & 143 \\
\hline R-squared & 0.56 & 0.6 & & 0.39 & 0.4 & & 0.68 & 0.72 & \\
\hline Number of countries & & 25 & 25 & & 13 & 13 & & 12 & 12 \\
\hline
\end{tabular}

Robust t statistics in parentheses

* significant at $10 \%$; ** significant at $5 \%$; *** significant at $1 \%$

E. Does Public Investment Matter for Growth?

As previously discussed, the broad literature on economic growth has provided mixed evidence on the link between public investment and economic growth. The 
literature on transition economies is not an exception. We extend the baseline model to add a measure of public investment (capital spending in percent of GDP) and confirm the previous findings (Table 7). The OLS results suggest a statistically significant, but weak, link between public investment and growth in countries where the government is relatively more effective; this link however is not confirmed by the other estimation methods.

Table 7. Determinants of Economic Growth 1992-2004 Does Public Investment Matter?

\begin{tabular}{|c|c|c|c|c|c|c|c|c|c|}
\hline & \multicolumn{3}{|c|}{ All Countries } & \multicolumn{3}{|c|}{ Relatively More Effective Government } & \multicolumn{3}{|c|}{ Relatively Less Effective Government } \\
\hline & $\begin{array}{l}\text { OLS } \\
\text { (1) }\end{array}$ & $\begin{array}{l}\text { Fixed Effects } \\
\text { (2) }\end{array}$ & $\begin{array}{c}\text { Random Effects } \\
\text { (3) }\end{array}$ & $\begin{array}{c}\text { OLS } \\
(1)\end{array}$ & $\begin{array}{l}\text { Fixed Effects } \\
\text { (2) }\end{array}$ & $\begin{array}{c}\text { Random Effects } \\
\text { (3) }\end{array}$ & $\begin{array}{l}\text { OLS } \\
(1)\end{array}$ & $\begin{array}{l}\text { Fixed Effects } \\
\text { (2) }\end{array}$ & $\begin{array}{c}\text { Random Effects } \\
\text { (3) }\end{array}$ \\
\hline War dummy & $\begin{array}{l}-1.42 \\
(0.45)\end{array}$ & $\begin{array}{l}-1.42 \\
(0.66)\end{array}$ & $\begin{array}{l}-1.54 \\
(0.72)\end{array}$ & $\begin{array}{l}-1.14 \\
(0.60)\end{array}$ & $\begin{array}{l}-0.93 \\
(0.49)\end{array}$ & $\begin{array}{l}-1.08 \\
(0.59)\end{array}$ & $\begin{array}{c}0.99 \\
(0.16)\end{array}$ & $\begin{array}{l}-1.5 \\
(0.37)\end{array}$ & $\begin{array}{c}-0.94 \\
(0.24)\end{array}$ \\
\hline Ln(inflation) (IMF) & $\begin{array}{c}-1.75 * * * \\
(5.19)\end{array}$ & $\begin{array}{c}-1.23 * * * \\
(3.75)\end{array}$ & $\begin{array}{c}-1.49 * * * \\
(4.89)\end{array}$ & $\begin{array}{c}-0.85^{* *} \\
(2.39)\end{array}$ & $\begin{array}{c}-1.05^{* * *} \\
(3.79)\end{array}$ & $\begin{array}{c}-1.02 * * * \\
(3.82)\end{array}$ & $\begin{array}{c}-2.02 * * * \\
(3.67)\end{array}$ & $\begin{array}{c}-1.58 * * \\
(2.37)\end{array}$ & $\begin{array}{c}-1.72 * * * \\
(2.95)\end{array}$ \\
\hline Fiscal balance (\%GDP) (IMF) & $\begin{array}{c}0.64^{* * *} \\
(6.12)\end{array}$ & $\begin{array}{c}0.83^{* * *} \\
(7.54)\end{array}$ & $\begin{array}{c}0.80^{* * *} \\
(7.93)\end{array}$ & $\begin{array}{c}0.79 * * * \\
(8.44)\end{array}$ & $\begin{array}{c}0.88^{* * *} \\
(8.01)\end{array}$ & $\begin{array}{c}0.87 * * * \\
(8.19)\end{array}$ & $\begin{array}{l}0.67 * * * \\
(5.04)\end{array}$ & $\begin{array}{c}0.74 * * * \\
(3.74)\end{array}$ & $\begin{array}{c}0.72 * * * \\
(4.28)\end{array}$ \\
\hline EDRD Index of small-scale privatization & $\begin{array}{c}0.81 \\
(1.08)\end{array}$ & $\begin{array}{c}4.63^{* * *} \\
(4.10)\end{array}$ & $\begin{array}{c}2.82^{* * *} \\
(3.17)\end{array}$ & $\begin{array}{c}0.89 \\
(1.00)\end{array}$ & $\begin{array}{l}2.67 * * \\
(2.17)\end{array}$ & $\begin{array}{l}1.85^{*} \\
(1.80)\end{array}$ & $\begin{array}{c}3.90 * * * \\
(2.77)\end{array}$ & $\begin{array}{c}5.07 * * * \\
(2.67)\end{array}$ & $\begin{array}{c}4.62^{* * * *} \\
(3.04)\end{array}$ \\
\hline EDRD Index of price liberalization & $\begin{array}{l}-1.55 \\
(0.65)\end{array}$ & $\begin{array}{c}-3.79 * * * \\
(2.86)\end{array}$ & $\begin{array}{c}-3.08^{* *} \\
(2.48)\end{array}$ & $\begin{array}{l}2.66^{*} \\
(1.85)\end{array}$ & $\begin{array}{l}-0.47 \\
(0.28)\end{array}$ & $\begin{array}{c}0.67 \\
(0.45)\end{array}$ & $\begin{array}{l}-4.17 \\
(1.31)\end{array}$ & $\begin{array}{c}-4.79 * * \\
(2.33)\end{array}$ & $\begin{array}{c}-4.53^{* *} \\
(2.41)\end{array}$ \\
\hline Public investment & $\begin{array}{l}-0.04 \\
(0.17)\end{array}$ & $\begin{array}{c}0.00 \\
(0.02)\end{array}$ & $\begin{array}{c}0.03 \\
(0.17)\end{array}$ & $\begin{array}{l}0.33^{*} \\
(1.73)\end{array}$ & $\begin{array}{c}0.12 \\
(0.46)\end{array}$ & $\begin{array}{c}0.19 \\
(0.81)\end{array}$ & $\begin{array}{l}-0.05 \\
(0.16)\end{array}$ & $\begin{array}{l}-0.01 \\
(0.03)\end{array}$ & $\begin{array}{l}-0.02 \\
(0.07)\end{array}$ \\
\hline Constant & $\begin{array}{c}13.7 \\
(1.43)\end{array}$ & $\begin{array}{c}7.7 \\
(1.21)\end{array}$ & $\begin{array}{c}12.06^{* *} \\
(2.15)\end{array}$ & $\begin{array}{l}-8.28 \\
(1.24)\end{array}$ & $\begin{array}{l}-1.04 \\
(0.16)\end{array}$ & $\begin{array}{l}-2.85 \\
(0.44)\end{array}$ & $\begin{array}{l}16.03 \\
(1.34)\end{array}$ & $\begin{array}{l}13.46 \\
(1.25)\end{array}$ & $\begin{array}{l}14.31 \\
(1.56)\end{array}$ \\
\hline Observations & 236 & 236 & 236 & 127 & 127 & 127 & 109 & 109 & 109 \\
\hline R-squared & 0.43 & 0.52 & & 0.52 & 0.55 & & 0.51 & 0.53 & \\
\hline Number of countries & & 24 & 24 & & 12 & 12 & & 12 & 12 \\
\hline
\end{tabular}

Robust $t$ statistics in parenthese

* significant at $10 \%$; ** significant at $5 \%$; *** significant at $1 \%$

\section{F. Model Uncertainty}

Up until now we have been using as a baseline model a parsimonious specification based on Fischer and Sahay (2000). This of course raises a few difficult questions: (i) are the fundamental determinants of growth themselves changing over time? (see Brock and Durlauf 2003 on model uncertainty); and (ii) are the determinants of growth the same across countries? We make a preliminary effort to account for model uncertainty in the last section using recently developed methods in Bayesian Model Averaging (see Raftery 1995; Raftery and others 1997; Fernandez and others 2001; Salai-Martin and others 2003). In brief, these methods average all possible models given a set of regressors and test for the likelihood that a variable is included in a model, using Bayesian Information Criterion (BIC)-based tests. Given $k$ number of regressors, the number of possible models (including the null model) is $2^{\mathrm{k}}$ (e.g., given 15 regressors, the total number of possible models is 32,768). This is computationally very intensive and routines have been developed only recently. Nonetheless, accounting for model uncertainty using Bayesian techniques (not shown), our preliminary analysis suggests that fiscal balance and inflation are still statistically significant determinants of growth. ${ }^{15}$

\footnotetext{
${ }^{15}$ We use the bicdrop procedure in Stata developed by Paul Millar.
} 


\section{Conclusion}

This paper extends the early empirical literature on economic growth in transition economies, with particular focus on fiscal policy variables (fiscal balance as well as selected expenditure components). It utilizes a parsimonious model drawn from Fischer and Sahay (2000) of economic growth as a function of initial conditions, stabilization, liberalization and structural reform, consistent with existing empirical literature (as summarized for example in Havrylyshyn 2001). The paper expands the data used in previous analyses by some 7 to 10 years, extends the baseline model, explores potential sources of nonlinearities in the relationship between growth and public finance. The main findings are summarized as follows.

First, the fiscal balance matters for growth. This is a departure from the "first generation" studies of economic growth that found little perceptible impact of fiscal balance on growth. This finding is nonetheless fully consistent with recent, growing evidence drawn from studies of fiscal consolidation in the region that a sound fiscal position boosts economic growth. The results are also based on a larger and more representative sample relative to the early literature on economic growth in transition economies.

Second, the size of government matters for economic growth and the impact is nonlinear. The results reported in this paper shed light on the inconclusive literature on the links size of government and economic growth, while adding a new nuance: Beyond indicative expenditure thresholds (in percent of GDP), public spending has a negative impact on growth, while at levels below this indicative cutoff, there is no measurable impact. These findings, while new, are not completely surprising. As government expenditures grow, they may be associated with larger distortionary taxation and regulatory activities, potential less efficient provision of services, and new opportunities for rent-seeking and corruption.

Finally, the quality of governance matters. The previous key finding is mitigated by the relative weakness of public sector institutions. In particular, the size of government has adverse consequences on growth, but not when the government is relatively more effective or public sector institutions are stronger. This is consistent with other strands of the literature that emphasize the interactions between growth and good policies (e.g., Burnside and Dollar 2000 and 2004). 


\section{REFERENCES}

Åslund, Anders and Nazgul Jenish. 2005. "The Eurasian Growth Paradox,” (Washington: Institute for International Economics).

Bajo-Rubio, Oscar. 2000. "A further generalization of the Solow growth model: the role of the public sector,” Economics Letters Vol. 68 (2000) 79-84

Barro, Robert J. 1991. "Economic Growth in a Cross Section of Countries,” Quarterly Journal of Economics v106, n2 (May 1991): 407-43

. 1990. "Government spending in a simple model of endogenous growth," Journal of Political Economy Vol. 98: S103-S125.

Campos, Nauro F. and Fabrizio Coricelli. 2002. "Growth in Transition: What We Know, What We Don't, and What We Should," Journal of Economic Literature, Vol. XL (September 2002) pp. 793-836.

Chen, Sheng-Tung; Lee, Chien-Chiang . 2005. "Government Size and Economic Growth in Taiwan: A Threshold Regression Approach,” Journal of Policy Modeling Vol. 27, No. 9 (December 2005): 1051-66.

Chu, Ke-young and Gerd Schwartz. 1994. "Output Decline and Government Expenditures in European Transition Economies," International Monetary Fund IMF Working Paper No. 94/68.

Coricelli, Fabrizio. 1997. "Fiscal Policy: A Long-Term View,” Fiscal policy in transition: Forum Report of the Economic Policy Initiative, No. 3: 39-52.

de Melo, Martha, Cevdet Denizer, and Alan Gelb. 1996 "Patterns of Transition from Plan to Market,” The World Bank Economic Review, Vol. 10, No. 3: pp. 397-424/

Dethier, Jean-Jacques, Hafez Ghanem, and Edda Zoli, 1999. "Does democracy facilitate the economic transition: an empirical study of Central and Eastern Europe and the Former Soviet Union,” Policy Research Working Paper No. 2194 (Washington: The World Bank).

Devarajan, Shanta and others. 2001. "Guidelines for the World Bank's Work on Public Expenditure Analysis and Support (including PERs),” mimeo (Washington: The World Bank).

Dowrick, Steve. 1996. "Estimating the impact of government consumption on growth: Growth accounting and endogenous growth models," Empirical Economics, Volume 21, Number 1 (March, 1996): 163-186. 
Fidrmuc, Jan. 2001. "Forecasting Growth in Transition Economies: A Reassessment,” mimeo, Center for European Integration Studies (ZEI), University of Bonn.

Fischer, Stanley and Ratna Sahay. 2000. "The Transition Economies After Ten Years," NBER Working Paper No. 7664 (Cambridge: National Bureau of Economic Research).

Fischer, Stanley, Ratna Sahay, and Carlos Vegh. 1996. "Stabilization and Growth in Transition Economies: The Early Experience,” Journal of Economic Perspectives, Vol. 10, No. 2 (Spring): 45-66.

Godoy, Sergio and Joseph E. Stiglitz. 2006 "Growth, Initial Conditions, Law and Speed of Privatization in Transition Countries: 11 Years Later," NBER Working Paper No. 11992 (Cambridge: National Bureau of Economic Research).

Grossman, Philip J, 1990. “Government and growth: Cross-sectional evidence,” Public Choice Vol. 65: 217-227. . 1988. "Government and economic growth: A nonlinear relationship," Public Choice Vol. 56(2): 193-200.

Gupta, Sanjeev and others. 2003. "Transition Economies: How Appropriate is the Size and Scope of Government?” Comparative Economic Studies, Vol. 45: 554-576.

Hansen, Bruce E. 2000. "Sample Splitting and Threshold Estimation,” Econometrica, Vol. 68, Iss. 3 (May): 575-603.

Havrylyshyn, Oleh. 2001. "Recovery and Growth in Transition: A Decade of Evidence," IMF Staff Papers, Vol. 48 (Special Issue): 53-87.

Havrylyshyn, Oleh, Ivailo Izvorski and Ron van Rooden. 1998. "Recovery and Growth in Transition Economies 1990-97: A Stylized Regression Analysis,” IMF Working Paper No. 98/141 (Washington: International Monetary Fund).

IMF. 2004 "Public Investment and Fiscal Policy,” (Washington: International Monetary Fund).

Knowles, Stephen, and Arlene Garces-Ozanne. 2003. "Government Intervention and Economic Performance in East Asia,” Economic Development and Cultural Change Vol. 51, Issue 2: 451-77.

Levine, Ross and David Renelt. 1992. "A Sensitivity Analysis of Cross-Country Growth Regressions,” American Economic Review v82, n4 (September 1992): 942-63.

Merlevede, Bruno. 2003. "Reform reversals and output growth in transition economies," Economics of Transition, Volume 11 (4): 649-669. 
Purfield, Catriona. 2003. "Fiscal Adjustment in Transition Countries: Evidence from the 1990s,” IMF Working Paper No. 03/36 (Washington: International Monetary Fund).

Sachs, Jeffrey D. 1996. “The Transition at Mid-Decade,” American Economic Review, Vol. 86, No. 2 (May): 128-133.

Selowsky, Marcelo and Ricardo Martin. 1997. "Policy Performance and Output Growth in the Transition Economies," American Economic Review, Vol. 87, No. 2 (May): 349-353.

World Bank. 2002. Transition: The First Ten Years (Washington: The World Bank). 


\section{DATA APPENDIX \\ Governance Indicators and Output Efficiency: Simple Correlations}

Our index of "government effectiveness," drawn from the World Bank Governance Indicators database, claims to measure "competence of the bureaucracy and the quality of public service delivery." Our other measure is an estimate of the average magnitude of bribes in percent of annual sales of surveyed firms, drawn from the BEEPS survey. How well does this score or index correlate with more "objective" measures of government efficiency? Herrera and Pang (2004) employ various methods of efficiency analysis using cross-country data on intermediate output indicators in education and public expenditures to estimate the "output efficiency" of governments. They produce indexes of how well governments produce education services for a given level of public resources. Among other indicators, they estimate the output efficiency index for secondary education enrollment (using data averaged over 1996-2002) based on Data Envelopment Analysis (DEA). For the 20 transition economies in the Herrera-Pang sample, the value of this index ranges from 0.57 to 0.83 , with higher values indicating greater efficiency. Notwithstanding the relatively small sample size, we examine how closely this index correlates with our measure of government effectiveness.

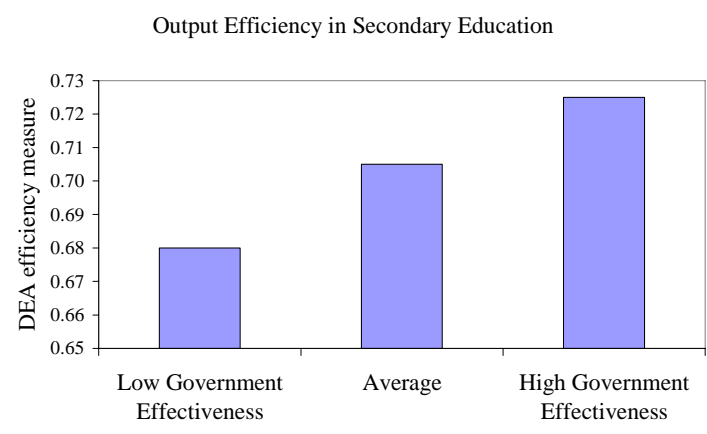

Figure 4 plots the output efficiency index separately for countries with relatively low and relatively high government effectiveness based on the median score of government effectiveness (the scores are between -2.5 and +2.5 , where higher score indicate greater effectiveness). The results suggest that where government effectiveness scores are higher, efficiency levels are higher as well, on average. An alternative analysis based on the average magnitude of bribes (our other measure of governance) yields basically the same figure. We test this more formally and run two bivariate regressions of output efficiency index on our (continues) measure of government effectiveness and our (continues) measure of the magnitude of bribes (percent of annual sales), respectively. The result indicates a statistically significant link, albeit weak, at the 10 percent level (with R-squares of 0.14 and 0.11 , respectively). 


\section{APPENDiX TABLES}

Appendix Tables 1-4 report the regression results based on equations 1, 2, and 3, using the growth data from national accounts (DDP); EBRD indexes of small-scale privatization, price liberalization, and overall reform progress; IMF data on inflation; and data from national authorities/World Bank (ECSPE) staff estimates for fiscal balances and public investments.

Appendix Tables 5-8 report the regression results based on equations 1, 2, and 3, using the growth data from national accounts (DDP); EBRD data for fiscal balances as well as indexes of small-scale privatization, price liberalization, and overall reform progress; IMF data on inflation; and data from national authorities/World Bank (ECSPE) staff estimates for public investments. 


\section{Appendix Table 1}

Determinants of Economic Growth, 1992-2004

\begin{tabular}{lccc}
\hline & & & \\
& OLS & Fixed Effects & Random Effects \\
& $(1)$ & $(2)$ & $(3)$ \\
\hline & & & -1.35 \\
War dummy & & & $(0.63)$ \\
& -1.15 & -1.15 & $-1.53^{* * *}$ \\
Ln(inflation) (IMF) & $(0.40)$ & $(0.54)$ & $(5.17)$ \\
& $-1.78^{* * *}$ & $-1.22^{* * *}$ & $0.75^{* * *}$ \\
Fiscal balance (\%GDP) & $(6.08)$ & $(3.74)$ & $(7.55)$ \\
EBRD Index of Small-Scale Privatization & $0.62 * * *$ & $0.76 * * *$ & $(3.23)$ \\
EBRD Index of Price Liberalization & $(5.16)$ & $(7.20)$ & $-3.15^{* * *}$ \\
& 0.85 & $4.94^{* * *}$ & $(2.59)$ \\
Constant & $(1.12)$ & $(4.41)$ & $12.04^{* *}$ \\
& -1.83 & $-3.59 * * *$ & $(2.31)$ \\
Observations & $(0.85)$ & $(2.75)$ & 242 \\
R-squared & $14.32^{*}$ & 5.39 & 24 \\
Number of countries & $(1.87)$ & $(0.88)$ & 242 \\
\end{tabular}

Robust $t$ statistics in parentheses

* significant at $10 \%$;* significant at $5 \%$; *** significant at $1 \%$

\section{Appendix Table 2}

Determinants of Economic Growth, 1992-2004: Using A Composite Measure of Reform Table 2. Determinants of Economic Growth, 1992-2004: Using composite measure of reform

\begin{tabular}{lccc}
\hline & & & \\
& OLS & Fixed Effects & Random Effects \\
& $(1)$ & $(2)$ & $(3)$ \\
\hline War dummy & & & -1.86 \\
& -1.55 & -1.83 & $(0.85)$ \\
Ln(inflation) & $(0.53)$ & $(0.82)$ & $-2.07^{* * *}$ \\
& $-2.12^{* * *}$ & $-2.00^{* * *}$ & $(6.66)$ \\
Fiscal balance & $(7.15)$ & $(5.31)$ & $0.75^{* * *}$ \\
& $0.65^{* * *}$ & $0.79 * * *$ & $(7.55)$ \\
Index of Reform Progress (IRP) & $(5.40)$ & $(7.29)$ & -0.19 \\
& $-0.22^{*}$ & -0.11 & $(1.46)$ \\
Constant & $(1.83)$ & $(0.55)$ & $16.15^{* * *}$ \\
& $16.63^{* * *}$ & $13.98^{* *}$ & $(4.19)$ \\
Observations & $(4.53)$ & $(2.53)$ & 242 \\
R-squared & & & 24 \\
Number of countries & 242 & 242 & 0.46 \\
\end{tabular}

Robust t statistics in parentheses

* significant at $10 \%$;** significant at $5 \%$; *** significant at $1 \%$ 
Appendix Table 3

Determinants of Economic Growth, 1992-2004: Varying Impact Over Time

By Government Effectiveness (WB Governance Indicator for Government Effectiveness)

\begin{tabular}{|c|c|c|c|c|c|c|}
\hline & \multicolumn{3}{|c|}{ Before 1998} & \multicolumn{3}{|c|}{1998 Onwards } \\
\hline & $\begin{array}{c}\text { OLS } \\
(1)\end{array}$ & $\begin{array}{l}\text { Fixed Effects } \\
\text { (2) }\end{array}$ & $\begin{array}{c}\text { Random Effects } \\
\text { (3) }\end{array}$ & $\begin{array}{l}\text { OLS } \\
\text { (1) }\end{array}$ & $\begin{array}{c}\text { Fixed Effects } \\
\text { (2) }\end{array}$ & $\begin{array}{c}\text { Random Effects } \\
\text { (3) }\end{array}$ \\
\hline War dummy & $\begin{array}{l}-0.62 \\
(0.20)\end{array}$ & $\begin{array}{l}-1.74 \\
(0.82)\end{array}$ & $\begin{array}{l}-1.47 \\
(0.71)\end{array}$ & $\begin{array}{l}-0.88 \\
(0.25)\end{array}$ & $\begin{array}{l}-2.64 \\
(1.23)\end{array}$ & $\begin{array}{c}-1.7 \\
(0.80)\end{array}$ \\
\hline Ln(inflation) & $\begin{array}{c}-1.68 * * * \\
(5.31)\end{array}$ & $\begin{array}{c}-1.77 * * * \\
(4.83)\end{array}$ & $\begin{array}{c}-1.68^{* * * *} \\
(5.25)\end{array}$ & $\begin{array}{c}-1.53 * * * \\
(4.18)\end{array}$ & $\begin{array}{c}-1.77^{* * * *} \\
(4.51)\end{array}$ & $\begin{array}{c}-1.58 * * * \\
(4.56)\end{array}$ \\
\hline Fiscal balance & $\begin{array}{c}0.67 * * * \\
(5.27)\end{array}$ & $\begin{array}{c}0.81 * * * \\
(4.51)\end{array}$ & $\begin{array}{c}0.77 * * * \\
(4.59)\end{array}$ & $\begin{array}{c}0.54^{* * *} \\
(4.18)\end{array}$ & $\begin{array}{c}0.64 * * * \\
(3.29)\end{array}$ & $\begin{array}{c}0.64 * * * \\
(3.54)\end{array}$ \\
\hline Fiscal balance * Dummy (for years htrough 1998) & $\begin{array}{l}-0.24 \\
(1.14)\end{array}$ & $\begin{array}{l}-0.24 \\
(1.23)\end{array}$ & $\begin{array}{l}-0.24 \\
(1.27)\end{array}$ & $\begin{array}{l}-0.12 \\
(0.58)\end{array}$ & $\begin{array}{l}-0.16 \\
(0.76)\end{array}$ & $\begin{array}{l}-0.14 \\
(0.70)\end{array}$ \\
\hline Index of Reform Progress & $\begin{array}{c}-0.48 * * * \\
(3.59)\end{array}$ & $\begin{array}{c}-0.58 * * * \\
(2.72)\end{array}$ & $\begin{array}{c}-0.51^{* * *} \\
(3.77)\end{array}$ & $\begin{array}{c}-0.46 * * * \\
(3.58)\end{array}$ & $\begin{array}{c}-1.11 * * * \\
(4.03)\end{array}$ & $\begin{array}{c}-0.54 * * * \\
(4.32)\end{array}$ \\
\hline Index of Reform Progress * Dummy (for years through 1998) & $\begin{array}{c}0.76 * * * \\
(3.62)\end{array}$ & $\begin{array}{c}0.76 * * * \\
(5.18)\end{array}$ & $\begin{array}{c}0.76 * * * \\
(5.39)\end{array}$ & $\begin{array}{c}0.68 * * * \\
(3.21)\end{array}$ & $\begin{array}{c}0.70^{* * *} \\
(4.76)\end{array}$ & $\begin{array}{c}0.67^{* * *} \\
(4.61)\end{array}$ \\
\hline Constant & $\begin{array}{c}23.06 * * * \\
(5.73)\end{array}$ & $\begin{array}{c}26.37 * * * \\
(4.38)\end{array}$ & $\begin{array}{c}24.15 * * * \\
(6.19)\end{array}$ & $\begin{array}{l}-0.45 \\
(0.09)\end{array}$ & $\begin{array}{c}41.45 * * * \\
(5.32)\end{array}$ & $\begin{array}{c}0.92 \\
(0.20)\end{array}$ \\
\hline Observations & 242 & 242 & 242 & 242 & 242 & 242 \\
\hline R-squared & 0.48 & 0.52 & & 0.52 & 0.57 & \\
\hline Number of countries & & 24 & 24 & & 24 & 24 \\
\hline
\end{tabular}

Robust t statistics in parentheses

* significant at $10 \%$; ** significant at $5 \%$; *** significant at $1 \%$

\section{Appendix Table 4}

Determinants of Economic Growth, 1992-2004:

Does Public Investment Matter?

\begin{tabular}{|c|c|c|c|c|c|c|c|c|c|}
\hline & \multicolumn{3}{|c|}{ All Observations } & \multicolumn{2}{|c|}{ OLS } & \multicolumn{2}{|c|}{ Fixed effects } & \multicolumn{2}{|c|}{ Random effects } \\
\hline & $\begin{array}{c}\text { OLS } \\
(1)\end{array}$ & $\begin{array}{l}\text { Fixed Effects } \\
\text { (2) }\end{array}$ & $\begin{array}{l}\text { Random Effects } \\
\text { (3) }\end{array}$ & $\begin{array}{c}\text { Low Gov Eff } \\
\text { (1) }\end{array}$ & $\begin{array}{l}\text { High Gov Eff } \\
\text { (2) }\end{array}$ & $\begin{array}{c}\text { Low Gov Eff } \\
\text { (1) }\end{array}$ & $\begin{array}{l}\text { High Gov Eff } \\
\text { (2) }\end{array}$ & $\begin{array}{c}\text { Low Gov Eff } \\
\text { (1) }\end{array}$ & $\begin{array}{c}\text { High Gov Eff } \\
\text { (2) }\end{array}$ \\
\hline War dummy & $\begin{array}{l}-1.22 \\
(0.42)\end{array}$ & $\begin{array}{l}-1.13 \\
(0.52)\end{array}$ & $\begin{array}{c}-1.3 \\
(0.60)\end{array}$ & $\begin{array}{c}1.27 \\
(0.22)\end{array}$ & $\begin{array}{l}-0.75 \\
(0.38)\end{array}$ & $\begin{array}{l}-0.76 \\
(0.19)\end{array}$ & $\begin{array}{l}-0.63 \\
(0.32)\end{array}$ & $\begin{array}{l}-1.38 \\
(0.34)\end{array}$ & $\begin{array}{l}-0.45 \\
(0.22)\end{array}$ \\
\hline Ln(inflation) & $\begin{array}{l}-1.80^{* * *} \\
(5.33)\end{array}$ & $\begin{array}{c}-1.22 * * * \\
(3.64)\end{array}$ & $\begin{array}{c}-1.52^{* * *} \\
(4.91)\end{array}$ & $\begin{array}{c}-1.97 * * * \\
(3.53)\end{array}$ & $\begin{array}{c}-0.89 * * \\
(2.52)\end{array}$ & $\begin{array}{c}-1.72 * * * \\
(2.96)\end{array}$ & $\begin{array}{c}-1.01^{* * *} \\
(3.54)\end{array}$ & $\begin{array}{l}-1.59 * * \\
(2.36)\end{array}$ & $\begin{array}{c}-1.01^{* * *} \\
(3.39)\end{array}$ \\
\hline Fiscal balance & $\begin{array}{l}0.61^{* * *} \\
(5.17)\end{array}$ & $\begin{array}{l}0.76^{* * *} \\
(6.89)\end{array}$ & $\begin{array}{c}0.75^{* * *} \\
(7.30)\end{array}$ & $\begin{array}{c}0.70^{* * *} \\
(4.68)\end{array}$ & $\begin{array}{c}0.75^{* * * *} \\
(6.78)\end{array}$ & $\begin{array}{c}0.71^{* * * *} \\
(4.28)\end{array}$ & $\begin{array}{c}0.80 * * * \\
(6.64)\end{array}$ & $\begin{array}{l}0.69 * * * \\
(3.54)\end{array}$ & $\begin{array}{c}0.80 * * * \\
(6.47)\end{array}$ \\
\hline EBRD Index: Small-Scale Priv & $\begin{array}{c}0.77 \\
(1.05)\end{array}$ & $\begin{array}{c}4.89 * * * \\
(4.27)\end{array}$ & $\begin{array}{c}2.82^{* * *} \\
(3.14)\end{array}$ & $\begin{array}{c}4.03^{* * *} \\
(2.86)\end{array}$ & $\begin{array}{c}1 \\
(1.02)\end{array}$ & $\begin{array}{c}4.58^{* * *} \\
(3.06)\end{array}$ & $\begin{array}{l}2.42^{* *} \\
(2.17)\end{array}$ & $\begin{array}{l}5.10 * * * \\
(2.67)\end{array}$ & $\begin{array}{c}3.46 * * * \\
(2.63)\end{array}$ \\
\hline EBRD Index: Price Lib & $\begin{array}{l}-1.83 \\
(0.77)\end{array}$ & $\begin{array}{c}-3.57 * * * \\
(2.65)\end{array}$ & $\begin{array}{l}-3.03^{* * *} \\
(2.40)\end{array}$ & $\begin{array}{l}-4.32 \\
(1.40)\end{array}$ & $\begin{array}{c}2.22 \\
(1.39)\end{array}$ & $\begin{array}{l}-4.41^{* *} \\
(2.35)\end{array}$ & $\begin{array}{c}0.39 \\
(0.24)\end{array}$ & $\begin{array}{l}-4.50^{* *} \\
(2.18)\end{array}$ & $\begin{array}{l}-0.76 \\
(0.42)\end{array}$ \\
\hline Public investment & $\begin{array}{l}-0.03 \\
(0.12)\end{array}$ & $\begin{array}{c}0.04 \\
(0.18)\end{array}$ & $\begin{array}{c}0.07 \\
(0.34)\end{array}$ & $\begin{array}{l}-0.01 \\
(0.03)\end{array}$ & $\begin{array}{c}0.32 \\
(1.61)\end{array}$ & $\begin{array}{c}0.02 \\
(0.06)\end{array}$ & $\begin{array}{c}0.18 \\
(0.72)\end{array}$ & $\begin{array}{c}0.03 \\
(0.09)\end{array}$ & $\begin{array}{c}0.12 \\
(0.43)\end{array}$ \\
\hline Constant & $\begin{array}{l}14.81 \\
(1.56)\end{array}$ & $\begin{array}{c}5.3 \\
(0.82)\end{array}$ & $\begin{array}{c}11.46^{* *} \\
(2.01)\end{array}$ & $\begin{array}{l}15.97 \\
(1.37)\end{array}$ & $\begin{array}{l}-7.17 \\
(1.02)\end{array}$ & $\begin{array}{l}13.79 \\
(1.52)\end{array}$ & $\begin{array}{l}-4.51 \\
(0.66)\end{array}$ & $\begin{array}{l}11.87 \\
(1.10)\end{array}$ & $\begin{array}{l}-3.74 \\
(0.52)\end{array}$ \\
\hline Observations & 236 & 236 & 236 & 109 & 127 & 109 & 127 & 109 & 127 \\
\hline $\begin{array}{l}\text { R-squared } \\
\text { Number of countries }\end{array}$ & 0.41 & $\begin{array}{c}0.51 \\
24\end{array}$ & & 0.52 & 0.46 & & 12 & 0.52 & $\begin{array}{c}0.49 \\
12\end{array}$ \\
\hline
\end{tabular}

Robust $\mathrm{t}$ statistics in parentheses. The country grouping is based on the median frequency of bribes.

* significant at $10 \%$; ** significant at $5 \%$; *** significant at $1 \%$ 


\section{Appendix Table 5}

Determinants of Economic Growth, 1992-2004

\begin{tabular}{lccc}
\hline & & & \\
& OLS & Fixed Effects & Random Effects \\
& $(1)$ & $(2)$ & $(3)$ \\
& & & $-4.54^{* * *}$ \\
War dummy & & & $(2.60)$ \\
& -4.66 & $-4.48^{* *}$ & $-1.47^{* * *}$ \\
Ln(inflation) (IMF) & $(1.62)$ & $(2.48)$ & $(5.31)$ \\
& $-1.76^{* * *}$ & $-1.22^{* * *}$ & $0.68^{* * *}$ \\
Fiscal balance (\%GDP) & $(5.81)$ & $(4.08)$ & $(8.30)$ \\
EBRD Index of Small-Scale Privatization & $0.60 * * *$ & $0.68^{* * *}$ & $(3.79)$ \\
EBRD Index of Price Liberalization & $(5.76)$ & $(7.68)$ & $-2.69^{* * *}$ \\
& $1.45^{* *}$ & $3.86^{* * *}$ & $(2.84)$ \\
Constant & $(2.09)$ & $(4.44)$ & $10.59^{* *}$ \\
& -1.78 & $-2.88^{* * *}$ & $(2.33)$ \\
Observations & $(1.29)$ & $(2.88)$ & 295 \\
R-squared & $12.04^{* *}$ & 6.64 & $(1.25)$ \\
Number of countries & $(1.97)$ & 295 & 25 \\
\end{tabular}

Robust t statistics in parentheses

* significant at $10 \%$; ** significant at $5 \%$; *** significant at $1 \%$

\section{Appendix Table 6}

Determinants of Economic Growth, 1992-2004: Using A Composite Measure of Reform

\begin{tabular}{lccc}
\hline & & & \\
& OLS & Fixed Effects & Random Effects \\
& $(1)$ & $(2)$ & $(3)$ \\
\hline War dummy & & & $-5.83^{* * *}$ \\
& $-5.70^{*}$ & $-5.86^{* * *}$ & $(3.30)$ \\
Ln(inflation) & $(1.90)$ & $(3.15)$ & $-1.91^{* * *}$ \\
& $-2.09^{* * *}$ & $-1.73^{* * *}$ & $(6.44)$ \\
Fiscal balance & $(7.32)$ & $(4.92)$ & $0.70^{* * *}$ \\
& $0.61^{* * *}$ & $0.74^{* * *}$ & $(8.56)$ \\
Index of Reform Progress (IRP) & $(5.78)$ & $(8.37)$ & -0.07 \\
Constant & -0.1 & 0.01 & $(0.58)$ \\
& $(0.91)$ & $(0.05)$ & $12.96^{* * *}$ \\
Observations & $13.76^{* * *}$ & $10.55^{* *}$ & $(3.53)$ \\
R-squared & $(3.76)$ & $(2.11)$ & 295 \\
Number of countries & & & 25 \\
& 295 & 295 & 25 \\
\hline
\end{tabular}

Robust t statistics in parentheses

* significant at 10\%; ** significant at 5\%; *** significant at $1 \%$ 


\section{Appendix Table 7}

Determinants of Economic Growth, 1992-2004: Varying Impact Over Time By Government Effectiveness (WB Governance Indicator for Government Effectiveness)

\begin{tabular}{|c|c|c|c|c|c|c|}
\hline & \multicolumn{3}{|c|}{ Before 1998} & \multicolumn{3}{|c|}{1998 Onwards } \\
\hline & $\begin{array}{l}\text { OLS } \\
(1)\end{array}$ & $\begin{array}{c}\text { Fixed Effects } \\
\text { (2) }\end{array}$ & $\begin{array}{l}\text { Random Effects } \\
\text { (3) }\end{array}$ & $\begin{array}{c}\text { OLS } \\
\text { (1) }\end{array}$ & $\begin{array}{c}\text { Fixed Effects } \\
\text { (2) }\end{array}$ & $\begin{array}{c}\text { Random Effects } \\
\text { (3) }\end{array}$ \\
\hline War dummy & $\begin{array}{c}-4.7 \\
(1.62)\end{array}$ & $\begin{array}{c}-5.79 * * * \\
(3.12)\end{array}$ & $\begin{array}{c}-5.36 * * * \\
(3.09)\end{array}$ & $\begin{array}{l}-4.67 \\
(1.63)\end{array}$ & $\begin{array}{c}-7.24 * * * \\
(3.93)\end{array}$ & $\begin{array}{c}-4.67 * * * \\
(2.80)\end{array}$ \\
\hline Ln(inflation) & $\begin{array}{c}-1.67 * * * \\
(4.23)\end{array}$ & $\begin{array}{c}-1.52 * * * \\
(4.22)\end{array}$ & $\begin{array}{c}-1.58 * * * \\
(5.04)\end{array}$ & $\begin{array}{c}-1.50 * * * \\
(3.84)\end{array}$ & $\begin{array}{c}-1.56^{* * * *} \\
(4.19)\end{array}$ & $\begin{array}{c}-1.50 * * * \\
(4.76)\end{array}$ \\
\hline Fiscal balance & $\begin{array}{c}0.51^{* * *} \\
(6.01)\end{array}$ & $\begin{array}{c}0.70^{* * *} \\
(4.07)\end{array}$ & $\begin{array}{c}0.62 * * * \\
(3.81)\end{array}$ & $\begin{array}{c}0.41 * * * \\
(4.80)\end{array}$ & $\begin{array}{c}0.68 * * * \\
(3.74)\end{array}$ & $\begin{array}{c}0.41 * * \\
(2.45)\end{array}$ \\
\hline Fiscal balance * Dummy (for years htrough 1998) & $\begin{array}{c}0 \\
(0.02)\end{array}$ & $\begin{array}{l}-0.07 \\
(0.37)\end{array}$ & $\begin{array}{l}-0.04 \\
(0.21)\end{array}$ & $\begin{array}{c}0.05 \\
(0.29)\end{array}$ & $\begin{array}{l}-0.12 \\
(0.63)\end{array}$ & $\begin{array}{c}0.05 \\
(0.25)\end{array}$ \\
\hline Index of Reform Progress & $\begin{array}{c}-0.38^{* * * *} \\
(3.00)\end{array}$ & $\begin{array}{l}-0.34^{*} \\
(1.69)\end{array}$ & $\begin{array}{c}-0.36 * * * \\
(2.74)\end{array}$ & $\begin{array}{c}-0.38 * * * \\
(3.13)\end{array}$ & $\begin{array}{c}-1.16^{* * * *} \\
(4.45)\end{array}$ & $\begin{array}{c}-0.38^{* * *} \\
(3.51)\end{array}$ \\
\hline Index of Reform Progress * Dummy (for years through 1998) & $\begin{array}{c}0.62^{* * * *} \\
(3.13)\end{array}$ & $\begin{array}{c}0.51^{* * *} \\
(3.45)\end{array}$ & $\begin{array}{c}0.56^{* * *} \\
(4.01)\end{array}$ & $\begin{array}{c}0.51^{* *} \\
(2.56)\end{array}$ & $\begin{array}{c}0.44^{* * * *} \\
(3.01)\end{array}$ & $\begin{array}{c}0.51^{* * * *} \\
(3.38)\end{array}$ \\
\hline Constant & $\begin{array}{c}20.45^{* * *} \\
(5.30)\end{array}$ & $\begin{array}{c}19.48^{* * *} \\
(3.39)\end{array}$ & $\begin{array}{c}20.18^{* * *} \\
(5.28)\end{array}$ & $\begin{array}{c}5.55 \\
(0.96)\end{array}$ & $\begin{array}{c}42.75^{* * * *} \\
(5.68)\end{array}$ & $\begin{array}{c}5.55 \\
(1.43)\end{array}$ \\
\hline $\begin{array}{l}\text { Observations } \\
\text { R-squared }\end{array}$ & $\begin{array}{l}295 \\
0.56\end{array}$ & $\begin{array}{l}295 \\
0.59\end{array}$ & 295 & $\begin{array}{l}295 \\
0.59\end{array}$ & $\begin{array}{l}295 \\
0.64\end{array}$ & 295 \\
\hline Number of countries & & 25 & 25 & & 25 & 25 \\
\hline
\end{tabular}

Robust t statistics in parentheses

* significant at $10 \%$; ** significant at $5 \%$; *** significant at $1 \%$

\section{Appendix Table 8}

Determinants of Economic Growth, 1992-2004:

Does Public Investment Matter?

\begin{tabular}{|c|c|c|c|c|c|c|c|c|c|}
\hline & \multicolumn{3}{|c|}{ All Observations } & \multicolumn{2}{|c|}{ OLS } & \multicolumn{2}{|c|}{ Fixed effects } & \multicolumn{2}{|c|}{ Random effects } \\
\hline & $\begin{array}{l}\text { OLS } \\
(1)\end{array}$ & $\begin{array}{l}\text { Fixed Effects } \\
\text { (2) }\end{array}$ & $\begin{array}{c}\text { Random Effects } \\
\text { (3) }\end{array}$ & $\begin{array}{c}\text { Low Gov Eff } \\
\text { (1) }\end{array}$ & $\begin{array}{c}\text { High Gov Eff } \\
\text { (2) }\end{array}$ & $\begin{array}{c}\text { Low Gov Eff } \\
\text { (1) }\end{array}$ & $\begin{array}{c}\text { High Gov Eff } \\
\text { (2) }\end{array}$ & $\begin{array}{c}\text { Low Gov Eff } \\
\text { (1) }\end{array}$ & $\begin{array}{c}\text { High Gov Eff } \\
\text { (2) }\end{array}$ \\
\hline War dummy & $\begin{array}{l}-1.75 \\
(0.53)\end{array}$ & $\begin{array}{l}-1.81 \\
(0.84)\end{array}$ & $\begin{array}{c}-1.94 \\
(0.91)\end{array}$ & $\begin{array}{c}0.36 \\
(0.05)\end{array}$ & $\begin{array}{l}-1.15 \\
(0.60)\end{array}$ & $\begin{array}{l}-1.94 \\
(0.50)\end{array}$ & $\begin{array}{l}-0.89 \\
(0.48)\end{array}$ & $\begin{array}{c}-2.61 \\
(0.64)\end{array}$ & $\begin{array}{c}-0.53 \\
(0.28)\end{array}$ \\
\hline Ln(inflation) & $\begin{array}{l}-1.79 * * * \\
(5.55)\end{array}$ & $\begin{array}{c}-1.29 * * * \\
(3.92)\end{array}$ & $\begin{array}{l}-1.53^{* * * *} \\
(5.03)\end{array}$ & $\begin{array}{c}-2.06 * * * \\
(3.89)\end{array}$ & $\begin{array}{l}-0.83^{* *} \\
(2.40)\end{array}$ & $\begin{array}{c}-1.73 * * * \\
(2.98)\end{array}$ & $\begin{array}{c}-1.00^{* * *} \\
(3.69)\end{array}$ & $\begin{array}{l}-1.61^{* *} \\
(2.45)\end{array}$ & $\begin{array}{c}-1.10^{* * *} \\
(3.86)\end{array}$ \\
\hline Fiscal balance & $\begin{array}{c}0.59^{* * *} \\
(5.44)\end{array}$ & $\begin{array}{c}0.76 * * * \\
(7.39)\end{array}$ & $\begin{array}{c}0.74 * * * \\
(7.80)\end{array}$ & $\begin{array}{c}0.63^{* * *} \\
(4.41)\end{array}$ & $\begin{array}{c}0.77 * * * \\
(8.47)\end{array}$ & $\begin{array}{c}0.70^{* * *} \\
(4.38)\end{array}$ & $\begin{array}{c}0.77 * * * \\
(7.83)\end{array}$ & $\begin{array}{c}0.73^{* * *} \\
(3.88)\end{array}$ & $\begin{array}{c}0.76^{* * *} \\
(7.37)\end{array}$ \\
\hline EBRD Index: Small-Scale Priv & $\begin{array}{c}1.06 \\
(1.41)\end{array}$ & $\begin{array}{c}4.80 * * * \\
(4.25)\end{array}$ & $\begin{array}{c}3.07 * * * \\
(3.44)\end{array}$ & $\begin{array}{l}4.24 * * * \\
(2.99)\end{array}$ & $\begin{array}{c}1.32 \\
(1.45)\end{array}$ & $\begin{array}{l}4.87 * * * \\
(3.22)\end{array}$ & $\begin{array}{l}1.80^{*} \\
(1.85)\end{array}$ & $\begin{array}{l}5.13 * * * \\
(2.72)\end{array}$ & $\begin{array}{l}2.74^{* *} \\
(2.16)\end{array}$ \\
\hline EBRD Index: Price Lib & $\begin{array}{l}-2.09 \\
(0.88)\end{array}$ & $\begin{array}{c}-4.07 * * * \\
(3.04)\end{array}$ & $\begin{array}{c}-3.50^{* * *} \\
(2.80)\end{array}$ & $\begin{array}{l}-4.85 \\
(1.57)\end{array}$ & $\begin{array}{l}2.43^{*} \\
(1.70)\end{array}$ & $\begin{array}{c}-5.03^{* * *} \\
(2.67)\end{array}$ & $\begin{array}{c}1.13 \\
(0.77)\end{array}$ & $\begin{array}{l}-5.27 * * \\
(2.54)\end{array}$ & $\begin{array}{l}-0.43 \\
(0.25)\end{array}$ \\
\hline Public investment & $\begin{array}{l}-0.05 \\
(0.20)\end{array}$ & $\begin{array}{c}0.01 \\
(0.05)\end{array}$ & $\begin{array}{c}0.03 \\
(0.16)\end{array}$ & $\begin{array}{l}-0.06 \\
(0.18)\end{array}$ & $\begin{array}{l}0.35^{*} \\
(1.85)\end{array}$ & $\begin{array}{c}0 \\
(0.02)\end{array}$ & $\begin{array}{c}0.2 \\
(0.88)\end{array}$ & $\begin{array}{c}0.03 \\
(0.09)\end{array}$ & $\begin{array}{c}0.05 \\
(0.19)\end{array}$ \\
\hline Constant & $\begin{array}{l}14.97 \\
(1.57)\end{array}$ & $\begin{array}{c}8.17 \\
(1.27)\end{array}$ & $\begin{array}{c}12.81^{* *} \\
(2.27)\end{array}$ & $\begin{array}{c}17.6 \\
(1.51)\end{array}$ & $\begin{array}{c}-9.17 \\
(1.42)\end{array}$ & $\begin{array}{l}15.40^{*} \\
(1.68)\end{array}$ & $\begin{array}{c}-4.84 \\
(0.74)\end{array}$ & $\begin{array}{l}15.09 \\
(1.39)\end{array}$ & $\begin{array}{l}-1.39 \\
(0.20)\end{array}$ \\
\hline Observations & 236 & 236 & 236 & 109 & 127 & 109 & 127 & 109 & 127 \\
\hline R-squared & 0.42 & 0.52 & & 0.51 & 0.53 & & & 0.53 & 0.53 \\
\hline Number of countries & & 24 & 24 & & & 12 & 12 & 12 & 12 \\
\hline
\end{tabular}

Robust t statistics in parentheses. The country grouping is based on the median frequency of bribes.

* significant at $10 \%$; ** significant at $5 \%$; *** significant at $1 \%$ 